\title{
DIDÁCTICA PARA UNA NACIÓN CATÓLICO-CONSERVADORA: LOS CUENTOS POPULARES DE ANTONIO TRUEBA*
}

\author{
POR \\ JAVIER PÉREZ NúÑ̃Z ${ }^{1}$ \\ Universidad Autónoma de Madrid
}

\begin{abstract}
RESUMEN
Informados por una estricta moral católica, por los fundamentos del conservadurismo social y por una concepción primordialista de la nación, los cuentos de Antonio Trueba eran muy del gusto de la burguesía moderada isabelina. Pero, por su ascendencia y pertenencia social, estaban escritos para entretener y atraer a las masas populares. Por eso su amplia difusión se debió a su lenguaje y argumentos, sencillos y de fácil comprensión, a su desarrollo en el ámbito local y al ruralismo costumbrista, que les acompaña. Con estos elementos Antonio Trueba imagina y enseña una nación virtuosa, vinculada al pueblo, pero ajena al principio de soberanía, que es la queremos aprehender y concretar en este artículo.
\end{abstract}

PALABRAS CLAVE: Antonio Trueba; País Vasco; Monarquía isabelina; nacionalismo; catolicismo; conservadurismo; ruralismo costumbrista; cuentos populares.

\section{DIDACTICS FOR A CATHOLIC-CONSERVATIVE NATION: THE FOLK TALES OF ANTONIO TRUEBA}

\begin{abstract}
The tale books of Antonio Trueba has held highly attractive for the moderate Elizabethan bourgeoisie since they deal about strict Catholic moral, principles of social conservatism and primordial conception of the nation. Thanks to their ancestry and social belonging, they were written to entertain and attract the popular masses. This is why, its wide diffusion was due to its simple and easy-to-understand language and arguments, to its development in the local area and to the rural customs, which accompany them. With these ingredients, imagines and teaches a virtuous nation, linked to the people, but oblivious to the principle of sovereignty, which is what we want to apprehend and concretize in this article.
\end{abstract}

KEY WORDS: Antonio Trueba; Basque Country; Elizabethan monarchy; Nationalism; Catholicism; Conservatism; rural tradition; folk tales.

Cómo CITAR ESTE ARTículo / CITATION: Pérez Núñez, Javier. 2020. «Didáctica para una nación católico-conservadora: los cuentos populares de Antonio Trueba». Hispania Sacra LXXII, 146: 551-567. https://doi.org/10.3989/hs.2020.041

Recibido/Received 05-12-2018

Aceptado/Accepted 26-11-2019

\section{APORTACIONES LITERARIAS AL IMAGINARIO NACIONAL-CATÓLICO}

El monumento con el que cuenta el literato, periodista, archivero y cronista de Vizcaya, Antonio Trueba Quintana,

* Este artículo se ha realizado en el marco del proyecto de investigación «Intercambios culturales y creación de identidades a través de la literatura, ss. XIX y XX» (HAR2016-76398-P). Una primera versión del mismo se presentó al congreso, "La nación omnipresente: nuevos enfoques sobre los procesos de nacionalización en la España contemporánea», 6-7 de septiembre de 2018, Museo do Pobo Galego / Facultade de Xeografía e Historia (USC), Santiago de Compostela.

1 javier.perez@uam.es /

ORCID iD: https://orcid.org/0000-0001-7574-0431 en la actual plaza Jardines de Albia de Bilbao, se erigió el 10 de noviembre de 1895 . Fue obra de uno de los escultores más laureados en la época, Mariano Benlliure, y en su momento tuvo un gran reconocimiento, convirtiéndose en un referente de la «iconografía de la naturalidad». Así, efigia al homenajeado sentado relajadamente en un banco público con un lápiz en la mano derecha y vestido de una manera un tanto desaliñada y descuidada. Solo le faltaba, para haberse acercado aún más a su verdadero semblante, el perpetuo cigarro en la boca. Además, queriendo evocar el amor de Antonio Trueba por la familia, le coloca mirando al domicilio en el que había residido desde que quedó viudo, la residencia de su hija y nietos en la calle Ibáñez de Bilbao. 
Esta escultura - ubicada en la citada plaza, que entonces, desde el fallecimiento del escritor en marzo de 1889, llevaba su nombre-, el retrato que cuelga en unas de las paredes del salón de sesiones de la Diputación de Vizcaya y la edición de las obras completas se llevaron a cabo con las aportaciones de esta corporación provincial, de la mayoría de los ayuntamientos vizcaínos y numerosas personas a título particular, entre las que se encontraban la colonia de emigrados vascos de Sudamérica y la propia familia de Antonio Trueba. Por lo tanto, fue el homenaje que brindó "toda Vizcaya» a uno de sus egregios hijos por la fama y el prestigio alcanzados en el mundo de las letras. ${ }^{2}$

Entonces la figura de Antonio Trueba estaba ya en franco declive, pero tuvo su época de esplendor. Fue en los años centrales de la Monarquía isabelina, los cincuenta y sesenta del ochocientos, cuando adquirió un cierto renombre y reconocimiento como literato. Así, sus obras, principalmente los poemas y cuentos, estaban en las estanterías de muchas bibliotecas, en la del Palacio Real y en las de las clases acomodadas y cultivadas, pero también en las más humildes de la gente que lo era menos en ambos aspectos, así como en alguna de las pobres escuelas. Además, muchos de sus títulos fueron publicados en distintos periódicos, algunos de sus libros fueron editados con el patrocinio real, traducidos a varios idiomas y leídos con fervor al otro lado del Atlántico, al menos por los emigrados vascos. En definitiva, gozó de una gran popularidad y constituyó un auténtico éxito editorial. ${ }^{3}$

Antonio Trueba adquirió esta celebridad haciéndose un hueco en la importante senda abierta por Fernán Caballero y contribuyendo con él (siempre cita en masculino a Cecilia Böhl de Faber) a la construcción cultural, desde la literatura, de la primera versión del nacional-catolicismo. Así, en su búsqueda romántica del "espíritu nacional», antes que nada, lo que pretendían era impedir que la confesión católica a través del reconocimiento de la tolerancia religiosa o de la libertad de cultos quedara relegada a un segundo plano o fuera reemplazada por la nación soberana y cívica contemplada en la revolución liberal. Algo que parecía factible si asumimos, siguiendo a importantes teóricos del nacionalismo - como Carlton Hayes y Benedict Anderson, por señalar a los más reconocidos- que en la nación y el nacionalismo se perpetúan secularizados muchos de los contenidos trascendentes, emocionales, ceremoniales y rituales de la religión. ${ }^{4}$ Desde otra perspectiva esto solo es posible con el dominio de la religión laica o la total laicización, ya que considera que, en los procesos de construcción nacional, existe una total imbricación entre la nación y la religión, pudiéndose conjugar perfectamente la pertenencia nacional con la identidad religiosa. ${ }^{5}$ Así, como significan Heinz-Gerhard Haupt y Dieter Langewiesche, la nación, como gran principio legitimador de los Estados liberales, en modo alguno desbancó a la religión como centro de

\footnotetext{
2 Becerro 1892, 54-55; 1896,111-152; Ereño 1998, 53-54 y Paliza 2004, 437-445.

3 Amores 1999, 61-63; Juaristi 1987, 135; Louis-Lande 1905, 320 y 343-344 y Múgica 1914, 51-55.

4 Hayes 1966 y Anderson 1993. Este tratamiento histórico del nacionalismo como una religión secularizada lo sigue también Mosse 2005.

5 Millán y Romeo 2010, 13-17.
}

valores de la sociedad, pero, con la pretensión de monopolizar de forma exclusiva la lealtad de sus miembros, exigió su supeditación bien mediante la laicidad bien mediante la confesionalidad del Estado. ${ }^{6}$ De ahí que las Cortes gaditanas protegieran la unidad religiosa estableciendo la «nación católica», mostrando, como subrayan José María Portillo y Gregorio Alonso, entre otros, la estrecha armonización existente entre la nación y la religión en la primera irrupción del nacionalismo español, al igual que ocurrió con la Constitución y los principios políticos liberales aprehendidos con las antiguas máximas e instituciones de la Monarquía y la mentalidad y lenguaje tradicionales. ${ }^{7}$ De esta manera, el anclaje de la nación católica gaditano sería muy importante para la cimentación del primer esbozo del nacional catolicismo, alumbrado desde mediados del XIX.

Pero, concluida la guerra de la independencia, la compatibilidad entre la exclusividad católica y la intolerancia religiosa con la nación soberana y cívica se mostró harto difícil, particularmente para el sector más radical del liberalismo Así, primero, durante el trienio liberal y, después, a partir de 1836 bajo las regencias de María Cristina y de Baldomero Espartero, al tiempo que se procedía al acotamiento legislativo del ámbito eclesiástico-religioso, se produjo una emancipación y afirmación de la nación soberana y cívica, sobre todo, por la estrecha connivencia de los prelados y de las órdenes religiosas con el absolutismo fernandino y el carlismo levantado en armas contra la nación liberal. ${ }^{8}$ La consolidación de los moderados en el poder trajo consigo la recuperación del modelo religioso exclusivo e intolerante gaditano y el acallamiento de la nación de todo lo que no tuviera que ver con su identificación confesional y monárquica, es decir, se la apartaba de la soberanía y se reducía el espacio cívico a la mínima expresión. ${ }^{9}$

Las revoluciones de 1848 y su traslación a España en el bienio progresista marcaron un antes y un después. Mostraron las grandes potencialidades movilizadoras y transformadoras de la nación, sobre todo, de las vinculadas a través el patriotismo republicano a la justicia social. Pues bien, para contrarrestarla el sector más retrógrado del conservadurismo la asumió sin ambages, pero saturándola de religión, produciéndose una cierta «sacralización o catolización de la nación ». ${ }^{10}$ Así, identificados la nación española y los españoles única y exclusivamente con el catolicismo, se procedió a su construcción cultural mediante, entre otras cosas, la definición de los principales soportes ideológicosdoctrinales con una impronta muy eclesial, la propuesta de articulación de un sistema político monárquico muy apegado a la constitución histórica, la relectura de la historia de acuerdo con el mito historiográfico nacional católico y la elaboración de un relato nacional que permitiera aprehender la comunidad imaginada bajo este mismo paradigma confesional. ${ }^{11}$

\footnotetext{
6 Haupt y Langewiesche 2010, 24-25.

7 Portillo 2000, 364-383 y Alonso 2014, 41-46 y 57-61. También Millán y Romeo 2015, 185-188. Para el debate sobre la nación católica en el primer liberalismo, Suárez 2014, 37-45.

8 Fuentes 2013, 169-196; Garrido 2013a y Pérez 2016, 179-182.

9 Garrido 2013b.

10 Haupt 2006, 162 y Louzao 2013, 74-76.

11 Una primera aproximación a este arranque de lo que luego será el nacional-catolicismo se puede seguir en la obra clásica de Botti 1992, 31-35.
} 
Para esta narración de la nación la literatura de ficción resulta una gran aportación porque no solo permite pensar en la nación, sino creer en la nación como algo tangible, ya que, como subraya Benedict Anderson, la sitúa en un espacio y un tiempo determinados y hacen sentir al individuo como sujeto inserto en ellos y, por lo tanto, como miembro de aquella. Así, para este antropólogo, las novelas (a las que sumamos los cuentos) constituyen un instrumento fundamental de nacionalización, ya que, a partir de la narración de simultaneidad de acontecimientos y situaciones, de coincidencias temporales, de sucesión de plurales (lugares, espacios), de la revelación de certezas interconectadas, etc. permiten a los individuos sentirse participes de una comunidad con la que comparten rasgos, entre los que se encuentran una lengua común y un relato colectivo. La máxima nacionalización se alcanza para Benedict Anderson cuando esos mismos individuos interiorizan esa comunidad y deviene en nación, al estar dispuestos a morir (y matar) en su nombre, es decir, cuando prevalece lo común en cada uno de ellos. En definitiva, a la manera rousseauniana, la nación es ante todo una comunidad de valores, ideas y costumbres, cuyos miembros están unidos por vínculos personales y afectivos y por una solidaridad derivada de su pertenencia al común nacional. ${ }^{12}$ Por lo tanto, para captar esta dimensión emocional las fuentes literarias también resultan muy valiosas.

Lo que pretende este estudio es explorar la cultura nacional destacada en los cuentos de Antonio Trueba para intentar conocer cuál fue su aportación a la construcción del imaginario nacional católico conservador. Consideramos que, aunque siguiera la estela de Fernán Caballero, tendría una cierta trascendencia, dada la difusión que tuvieron durante el reinado isabelino. Con todo, si puede resultar excesivo considerarle un productor o creador de nación adscrito a la esfera oficial, siempre es importante el estudio de su esfera privada como «instrumento de personalización de la nación» o para observar su "experiencia de nación». ${ }^{13}$

Pues bien, para constatar esta repercusión, orientados un tanto por Isabel Burdiel, ${ }^{14}$ procedemos, en primer lugar, a identificar al autor a través de su trayectoria vital. En segundo lugar, definimos el contexto y el ideario católico conservador en que se sitúa Antonio Trueba. En tercer lugar, intentamos clarificar el significado del carácter popular otorgado por el autor vizcaíno a sus cuentos. En cuarto lugar, abordamos los contenidos de estas narraciones siguiendo lo que para Antonio Trueba son los principios cardinales, "Dios, la patria y la familia». Y, finalmente, terminamos con unas conclusiones.

\section{ANTÓN EL DE LOS CANTARES}

Antonio Trueba comenzó a despuntar como literato a partir de la publicación en 1851 de El libro de los cantares. Tuvo una gran aceptación y empezó a ser conocido como se autodenominó en el poema introductorio, "Antón el de los cantares». Un sobrenombre que se ajustaba bastante

12 Principalmente, Anderson 1993, 22-76. También hemos seguido las reflexiones sobre las relaciones con la literatura contenidas en: Bhabha 2010, 11-19 y 187-207 y Andreu 2016, 15-19.

13 Quiroga 2013, 27-28 y 33.

14 Burdiel 2015, 273-281. bien con el carácter popular y sentimental de los recuerdos glosados en la obra, con la manera como la había realizado que, como decía en el prólogo, la había hecho como sabía "a la buena de Dios, como los componía el pueblo», y también se adecuaba con su origen social y formación.

Antonio Trueba nació el 24 de diciembre de 1819 en el Concejo de Galdames, en la zona minera de las Encarnaciones vizcaínas, en el seno de una familia humilde de labradores. De esta manera, su formación básica, compatibilizándola con el trabajo en el campo, se redujo a la recibida en la escuela pública de Sopuerta, concejo limítrofe con Cantabria al que se trasladó al poco y en donde residió hasta los 16 años. Entonces, para evitar ser reclutado durante la primera guerra carlista, migró a Madrid para trabajar en la ferretería de un primo de su madre. Fue aquí donde, asentándose en la afición que desde chaval le producían los romances de ciego, canciones y cuentos, se abrió un tiempo de formación autodidacta a través de las impresiones que le produjeron el Madrid liberal de las Regencias y la lectura de los principales autores románticos españoles del momento, destacando, por la conmoción que le provocó y la decisiva influencia que tuvo en su obra poética, Lo Gayter del Llobregat de Joaquín Rubio Ors.

Pues bien, con este escueto bagaje cultural, ya bajo el reinado efectivo de Isabel II y el dominio de los moderados, Antonio Trueba comenzó a vislumbrar un horizonte como literato. Fue muy importante para ello el empleo que en 1845 consiguió en el Ayuntamiento de Madrid, aunque solo fuera por tres años. Pero más valor tuvo aún el círculo de amistades literarias, como las que trabó, entre otros, con José Castro y Serrano, Luis de Eguilaz, Pedro Antonio Alarcón, Antonio Arnao o Carlos de Pravía, formando con ellos la asociación virtual "La Colonia del Pensamiento». Abierta de esta manera la república de las letras, escribió sus primeras y fallidas novelas históricas, entabló nuevas relaciones (principalmente con Juan Eugenio Hartzenbusch y, sobre todo, con Fernán Caballero, referente y modelo de su obra en prosa) y realizó distintas colaboraciones periodísticas en diarios de signo muy conservador, como La España, La Esperanza o La Época, y aportaciones literarias en la Revista Vascongada o el Semanario Pintoresco Español, donde empezó a publicar sus cuentos.

El éxito logrado con El libro de los cantares le allanó el camino para su carrera literaria. Lo facilitó y mucho que desde 1853 pudiera ocupar un puesto en la redacción de la Correspondencia de España, la moderna empresa periodística fundada por Manuel María de Santa Ana. Y, teniendo de esta forma medios para seguir dedicándose a la literatura, la fama le amplió las posibilidades para publicar sus nuevas narraciones. Así, contó con una nueva revista, El Correo de la Moda, donde aparecieron por primera vez los cuentos que después formarían sus libros más famosos: Cuentos de color de rosa (1859), Cuentos campesinos (1860) y Cuentos populares (1862).

La espléndida acogida de estas obras y la popularidad aparejada cambiaron la vida de Antonio Trueba. Se le abrieron canales y reconocimientos de un nivel superior, como los de la Corte y de la propia reina, para quien fue uno de los poetas preferido y costeó la reedición de alguna de sus obras, o los de la tertulia "La Esmeralda», que reunía a lo más egregio de la literatura y la política del momento, de la 
Unión Liberal. De todas formas, mucho más importante que todo esto para Antonio Trueba fueron el matrimonio que contrajo en 1859 con la madrileña Teresa Prado García y el nacimiento de su única hija, Ascensión. ${ }^{15}$

La posición y celebridad alcanzadas, particularmente en Madrid, pero también la estricta moral católica y el doble patriotismo moderado-fuerista a los que se ceñían sus escritos, fueron las razones que estuvieron detrás de su nombramiento en 1862 como archivero y cronista del Señorío de Vizcaya por las Juntas Generales, a propuesta de la Diputación Foral y contando con el respaldo de Irurac Bat y Euscalduna, dos de los periódicos entonces más influyentes. Antonio Trueba, que desde que abandonó Vizcaya en 1836 hasta su viaje de novios a Las Encartaciones no había vuelto, desoyó los consejos de sus amigos literatos para que permaneciera en la república de las letras, donde se había labrado un cierto nombre, y optó por la república foral.

Parece que acertó - como a posteriori apuntó Antonio Trueba- porque entonces se abrió la etapa más feliz de su vida, ya que pudo compatibilizar, además de manera muy fructífera, las dos actividades, la literaria y la de cronista. Así, tras realizar en 1864 su carta de presentación en el nuevo cargo con el variopinto Capítulos sentidos y pensados viajando por las provincias Vascongadas, en la primera de las tareas acometió una profunda revisión de una de sus novelas históricas, convirtiéndose para él en algo bastante aceptable (La paloma y los halcones, 1865). También, vieron la luz en 1866 dos nuevas recopilaciones de cuentos (Cuentos de vivos y muertos, contados por el pueblo y Cuentos de varios colores) y al año siguiente publicó, siguiendo el modelo de El libro de los cantares, El libro de las montañas. Esta obra, que es un canto apasionado a un idílico País Vasco, participaba ya de la inclinación tradicionalista del fuerismo que, en el desarrollo de la segunda de las tareas, se produjo al unísono con las instituciones forales de las que formaba parte. Una basculación que, aunque no afectara al status quo foral, se manifestó a partir del debate que se planteó en el Senado en 1864 sobre la realidad vascongada. Antonio Trueba se sumó a la salvaguarda de ésta, ratificando la mitología historiográfica foral sustentada por Pedro Novia de Salcedo (Defensa de un muerto atacado por el Excmo. Sr. D. Manuel Sánchez Silva, 1865) y elaborando una memoria en la que mostraba a la comunidad foral vizcaína como modelo de organización social («Bosquejo de la organización social de Vizcaya», 1867) que, presentada a la exposición universal de París de este año, recibió una mención honorífica. Y, en su caso, también mantuvo la fidelidad más estrecha, además de a la religión católica y a la singularidad de las Vascongadas enarboladas por el fuerismo tradicionalista, a la Monarquía Isabel II, más allá del viaje que ésta realizó en 1865 a estas provincias, en el que la acompañó en calidad de cronista. ${ }^{16}$

Por esta razón, aunque la revolución democrática y laica de 1868 -límite cronológico de este estudio- fuera para Antonio Trueba una auténtica debacle, nunca comulgó con

15 Para esta primera etapa de la vida de Antonio Trueba hemos seguido, fundamentalmente: Amores 1999, 17-19 y 24-25; Becerro 1892, 17-19 y 20-21; Ereño 1998, 29 y 82; Louis-Lande 1905, 324-328 y Trueba 1862 a, $9-10$ y 396; $1867,247-248$ y 318-319 y $1878,2-8$.

16 Para este segundo tramo: Ereño 1998, 37-40; González-Blanco 1914, 14-17; Trueba 1889, 62 y Urquijo 2000, 12 y 28. el carlismo. A pesar de ello, la connivencia de la Diputación vizcaína con la fallida sublevación carlista de agosto de 1870, provocó su destitución como archivero y, cristalizada ya la nueva guerra carlista, su retorno a Madrid en septiembre de 1873. Durante este tiempo, para poder subsistir, intensificó su labor periodística y literaria, pero manteniendo incólume su conservadurismo fuerista católico. En la primera ocupación, destacaron sus colaboraciones en La Época, La Ilustración Española y Americana, y, sobre todo, en el periódico alfonsino y canovista, El Correo Vascongado, del que fue primer redactor. $Y$, en la segunda actividad, en las principales publicaciones, persiste en la temática patriarcal y ruralista del País Vasco (Cielo con nubecillas, recuerdos de la vida rural y familiar de Vizcaya, 1871) y en el adoctrinamiento familiar en una estricta moral católica (Narraciones Populares y MariSanta: cuadros de un hogar y sus contornos, 1874 y Cuentos del hogar, 1875), a la par que acentúa sus alegatos contra la revolución y la modernización (El gabán y la chaqueta, 1872, Alrededor de Madrid, 1874 y El redentor moderno, 1876). ${ }^{17}$

Concluido el conflicto carlista, en abril de 1876 regresó a Bilbao y recuperó su puesto de archivero y cronista del Señorío de Vizcaya. En calidad de tal redactó las exposiciones de las Diputaciones vascongadas en favor del mantenimiento de los regímenes forales. Con la abolición de éstos, Antonio Trueba rompió su relación ideológico afectiva con la Monarquía isabelina, pero sobre todo con la alfonsina, y se convirtió en el mentor espiritual del fuerismo intransigente. Así, a partir de entonces, colaboró en muchas de sus publicaciones (La Paz, La Revista de las Provincias Euskaras, Revista Euskara, Revista Euskal-Herria...) y dirigió la sección literaria de El Noticiero Bilbaíno. Por supuesto, además de su labor como cronista e historiador, de muy escaso valor, hasta el final de sus días siguió narrando cuentos populares (Cuentos de madres a hijos, 1878; Nuevos cuentos populares, 1880; y De flor en flor, 1882). ${ }^{18}$

\section{LA NACIÓN CATÓLICA-CONSERVADORA}

Al publicarse la primera edición de los Cuentos campesinos, Juan Mañé y Flaquer señaló que veía en Antonio Trueba un cierto distanciamiento de la escuela literaria neocatólica, a la que, en su opinión, pertenecían los anteriores Cuentos de color de rosa. En 1862, en el prólogo de la segunda edición de esta obra, el escritor encartado al rebatir tal alineamiento, no teniendo muy clara la definición de neocatólico, lo que hizo fue, si no confirmar dicha adscripción, sí su ubicación en un conservadurismo católico tradicionalista: era "un católico de siempre» - diría-, que «creía que Dios y la familia eran la única esperanza y el único refugio del pueblo en las tempestades de la vida». Así es, tanto él como Fernán Caballero, al que al parecer tampoco agradaba que de manera reduccionista tildaran de neocatólico, ${ }^{19}$ se encua-

17 Para la vida de Antonio Trueba durante el sexenio: Amores 1999, 34-35 y 51-53; Becerro 1892, 44-46; Ereño 1998, 41-45 e Iglesia 1975, 26-27.

18 Para esta última etapa: Becerro 1892, 37 y 43; Ereño 1998, 50, 55 y 142 y Juaristi 1987, 136.

19 Trueba 1862b, 10-14; Amores 1999, 27-30 y 2001, 24-25. También Andreu 2012, 10-11, que muestra el tránsito desde el distanciamiento del moderantismo clásico al efusivo acercamiento al neocatolicismo. 
dran en el ala monárquica autoritaria del moderantismo, que empezó a ser muy influyente a partir de 1848.

En efecto, las revoluciones de este año con su carácter social y democrático produjeron un cierre de filas en la militancia conservadora y una deriva reaccionaria del régimen moderado. Así, durante la misma se presentaron distintos proyectos involucionistas de reforma constitucional, destacando el apadrinado por Juan Bravo Murillo, con el objeto de actualizar en sentido retrógrado la constitución histórica. En este contexto y también bajo el predominio del grupo monárquico autoritario del partido moderado, que contaba con gran ascendiente en el entorno del Palacio Real, se concluyeron las negociaciones para la firma en 1851 del Concordato con la Santa Sede. Con éste se reforzaba la confesionalidad católica del Estado declarada por la Constitución de 1845, al hacerla exclusiva «con exclusión de cualquier otra», y se sumaba a la Iglesia católica a la protección, que a dicha religión ya le brindaba la legislación de imprenta y la penal, al asumir la facultad de fiscalizar los libros religiosos y la enseñanza en todos los niveles y establecerse el matrimonio católico como el único legal entre los españoles. ${ }^{20}$

También en este tiempo y bajo los mismos parámetros ideológicos conservadores se produjo un acuerdo, más tácito que explícito, sobre el encaje de la situación foral de las Vascongadas en la Monarquía isabelina. Por el mismo, éstas aceptaban la uniformidad judicial y aduanera, así como el restrictivo sistema electoral municipal común (algo, más que aceptado, requerido) y el mantenimiento del culto y el clero de sus provincias, a cambio el Gobierno central renunciaba a seguir con ellas la senda navarra y a introducir más modificaciones, a exigir los cupos de contribuciones y quintas que se fijaran a las provincias y a proceder a la «estatalización» de las administraciones forales. Una concertación que fue factible por la sintonía ideológica entre los moderados y fueristas - los moderados vascongados- y por la estrecha conexión de ambos con la Monarquía isabelina. Esta vinculación monárquico-conservadora se afianzó porque de aquí arrancaron unos nuevos regímenes forales que, teniendo a las Diputaciones forales como sus piedras angulares, acabaron confiriendo a las Vascongadas unos niveles de autogobierno hasta entonces nunca alcanzados. ${ }^{21}$

Reafirmada la religión católica y la constitución histórica, al menos la de las Vascongadas, y vaciada la nación, ya desde la Constitución de 1845 , de su carácter soberano y cívico, al fundamentar el régimen en el principio de la soberanía compartida entre el Rey y las Cortes, para algunos había llegado el momento de incorporarla a la construcción conservadora por su valor como instrumento de integración social. Así lo entendió, entre otros, Jaime Balmes, principal ideólogo y alma mater del periódico de la tendencia monárquica autoritaria, cuyo título, El Pensamiento de la Nación, marca ya la evolución de esta opinión sobre la nación. Y lo hizo a través de su identificación con el catolicismo porque, para el clérigo catalán, junto con la institución monárquica, había modelado la «manera de ser» histórica y esencial de España. Asentándose en estos sólidos cimientos, fue

20 Para el contexto: Burdiel 2010, 214-244. Para los proyectos: Marcuello 2016. Para el concordato y medidas en favor del catolicismo: Alonso 2014, 200-208; Callahan 1989, 187-192 y Suárez 2014, 49-51.

21 Pérez 2002, 216-222.
Cándido Nocedal el artífice de la que puede considerar primera versión del nacional-catolicismo, al afirmar en 1855, en el debate parlamentario sobre la tolerancia religiosa, que el catolicismo era lo definitorio de lo español: "La nación española, que solo es conocida en Europa por su unidad religiosa y por ella respetada, dejaría de serlo si los españoles no tuvieran la misma religión, la católica, que es sin duda alguna [...] el rasgo más pronunciado de la fisonomía española, como lo ha sido siempre».

El mencionado diputado, al que ya se le podía calificar de neo-católico, finalizó su participación en esa discusión sosteniendo que la religión católica era el único antídoto contra el desorden social. ${ }^{22}$ Y es que no está de más recordar que, detrás de la versión católica de la nación de los moderados, no se pretendía recuperar desarrollo ciudadano alguno, sino reforzar con el refrendo confesional los principios y valores conservadores que, como la familia tradicional patriarcal, la dignidad del trabajo y el esfuerzo, la aceptación de la jerarquía y del orden social establecido, el respeto a la propiedad y a los derechos adquiridos, la fidelidad a las costumbres y tradiciones y, por supuesto, la observancia de los ritos y de las ceremonias religiosas, querían rigieran en la vida de los españoles. ${ }^{23}$

Pues bien, para intentar dar forma a este modelo social conservador después del bienio progresista, los referentes ideológicos del nacional-catolicismo fueron la cultura de resistencia al liberalismo del catastrofista apocalíptico José Donoso Cortés y las doctrinas anti-modernas y anti-liberales contenidas en la encíclica Quanta Cura y en el edicto pontificio Syllabus errorum. ${ }^{24}$ De acuerdo con estos presupuestos, la práctica política desarrollada durante la última década de la Monarquía isabelina por los Gobiernos del partido moderado (con mayor o menor peso de las tendencias extremas, neocatólica y monárquica autoritaria) tuvo una clara orientación reaccionaria y autoritaria. Así, «la religión, la moral, la monarquía, la constitución, la dinastía reinante y los cuerpos colegisladores" se convirtieron en el gran anatema contra los que se prohibía manifestarse, escribir o enseñar y, para impedirlo, se suspendieron las garantías constitucionales, se aprobó una normativa draconiana de orden público y se afirmó desmedidamente el poder del ejecutivo, así como se instauró la censura previa, amordazando a la prensa, y se depuró a los profesores y contenidos de las enseñanzas, afirmando la tutela eclesiástica. ${ }^{25}$

Al tiempo que de esta manera se intentaba acallar a las disidencias - por cierto, cada vez mayores - se hacía proselitismo a través de distintas asociaciones y sellos editoriales de carácter confesional y mediante una pléyade de periódicos (destacando El Pensamiento Español, Diario católico, apostólico y romano, propiedad de Francisco Navarro Villoslada). Además de acudir a estos medios, para afirmar un espacio discursivo católico se procedió también

22 Para el giro antinacional de los moderados: Garrido 2013b, 280-282. Para la primera versión del nacional-catolicismo: Álvarez 2001, 306-307, 406-408 y 412-413; Andreu 2016, 165-168; Romeo $2010,130-156$; Urigüen $1981,68-73$ y $116-122$ y para el sustrato de la nación católica balmesiana Villalonga 2012, 52-61.

23 López Aranguren 1982, 78-124 y Zavala 1989, 158-159.

24 Alonso 2014, 230-237 y Urigüen 1981, 57-61 y 124-136.

25 Ballbé 1983, 189-192; Callahan 1989, 224-226; Castro 1998, 83-96 y 212-235; y un caso regional de esta involución conservadora en Inarejos 2008, 308-312 y 316-329. 
a reelaborar la historia académica de acuerdo con el mito historiográfico nacional-católico, de manera que España surgía como nación a través de su identificación con el cristianismo, convirtiéndose en héroes nacionales, Santiago apóstol, Recaredo, don Pelayo, el Cid, etc., y en momentos estelares la conversión al catolicismo, la reconquista y los reinados de los Reyes Católicos y de Carlos V y Felipe II que, con la unidad política y religiosa y salvaguarda de España de la reforma protestante, se presentaban como portaestandartes del catolicismo. Y, para contrarrestar a los folletines y a la novela social, que propagaban doctrinas e ideas disgregadoras del orden establecido, se recurrió a una narración literaria (novelas y cuentos) que, con un carácter instructivo y moralizador, sirviera para revitalizar entre los españoles los principios y valores del catolicismo conservador. ${ }^{26}$

Pues bien, si la hispano-alemana Cecilia Böhl de Faber constituyó el arquetipo de esta literatura - de ahí que, a la gran musa de neocatolicismo, como la califica Xavier Andreu Miralles, demócratas y progresistas tildaran de Chateaubriand femenino-, el vizcaíno Antonio Trueba fue su fiel seguidor, su escudero. Así, como gran conocedor y admirador de su obra - se la llevó de lectura durante su viaje de novios y la invocó como oráculo y referenció como modelo en varios de sus cuentos, considerándola como la "gran fotógrafa de costumbres»-, el autor encartado, en la misma búsqueda del carácter o el espíritu nacional, lo que hizo fue sustituir el escenario del campo andaluz utilizado por aquella por, principalmente, el rural vasco (sobre todo, el de su comarca natal vizcaína) y, secundariamente, el madrileño. A partir de aquí siguió la pautas literarias e ideológicas del Fernán Caballero y, rechazando las Ilamadas novelas populares porque - advertía Antonio Trueba"con la hipocresía populachera» daban pábulo a una moral en la que «de Dios, de la sociedad, de la familia y de la propiedad no quedaba ni rastro", sus narraciones de carácter costumbrista eran exactamente lo contrario, la quintaesencia del catolicismo conservador. Así, considerando al mundo rural como el lugar donde se encontraba la verdadera esencia nacional, lo revelaba como una sociedad ejemplar de acuerdo con esa moral, ya que encarnaba la religiosidad, la salvaguarda de las buenas costumbres y tradiciones, el amor a la familia, al trabajo y al esfuerzo, el respeto al orden y a las jerarquías reconocidas, la naturalidad, austeridad, sencillez y conformismo. Estos rasgos se sublimaban para el literato vizcaíno en el País Vasco, donde, gracias a la pervivencia del régimen foral, hacían de él un lugar idílico, una arcadia feliz. ${ }^{27}$ En definitiva, como señala Jon Juaristi, venía a simbolizar que ideal conservador de una sociedad bajo patrones jerárquicos y de orden era realizable.

Antonio Trueba, que formó parte de la generación isabelina del fuerismo literario, contribuyó con José María Goizueta, Francisco Navarro Villoslada y Juan Venancio Araquistaín, principalmente, a la construcción cultural de la tradición vasca, sobre todo, con esa imagen idílica del

26 Para las asociaciones y prensa: Urigüen 1981, 140-141 y $163-$ 188 y Mínguez 2016, 43 y 91. Para el nuevo paradigma historiográfico: Álvarez 2001, 417-431. Y para la literatura católica: Andreu 2016, 320326 y Mínguez 2017, 131-137.

27 Para el nacional-catolicismo y seguidismo de Fernán Caballero: Amores 1999, 53-54 y 172-175; Andreu 2016, 210 y 320-327; Juaristi 1989, 57-58; Múgica 1914, 44 y 50 y Zavala 1989, 123-125. ruralismo paternalista. Igualmente lo hizo con novelas históricas o leyendas que, como La paloma y los halcones (reelaboración de El Señor de Bordero, publicado en 1849) o Jaun Zuría - considerado primer señor de Vizcaya-, permitieron difundir los grandes mitos fueristas como el monoteísmo primitivo, la independencia originaria, la incorporación pactada a la Corona de Castilla, el igualitarismo y disfrute ancestral de las libertades, la pureza de sangre e hidalguía universal. ${ }^{28}$

Pero también participó en la invención de la tradición española, sumándose a la construcción legendaria de El Cid (El Cid Campeador, 1851 y Las hijas del Cid, 1859), pero, sobre todo, en la identificación nacional con el catolicismo. De esta manera, Antonio Trueba aparece como uno de los más claros ejemplos de fidelidades compartidas, vasca (principalmente, vizcaína) y española. Pero este doble patriotismo, con distintas significaciones ideológicas, en nuestro autor se enmarcaba en un conservadurismo muy estrecho, en que invariablemente anteponía el orden a las libertades, la Corona a las Cortes y, por encima de todo, la religión. Siempre el catolicismo ocupaba el primer lugar, pero, principalmente, a partir de que los preceptos de Pío IX condenaran el progreso y la modernidad en su conjunto. Así, coincidiendo su promulgación con el debate en Senado sobre la singularidad vasca, sirvió para el rearme foral en clave católica, para la articulación de foral-catolicismo. Sintetizado en lema Jaungoikoa eta Foruak, presentaba al País Vasco foral, en cuanto al lugar más cercano a la tradición, como la vanguardia del catolicismo, como una especie de oasis contrarrevolucionario y, por ello, el mejor escudo protector contra las "perniciosas innovaciones extranjeras ${ }^{29}$ que, para Antonio Trueba, con la revolución de 1868 se habían adueñado ya de las principales ciudades españolas. ${ }^{30}$

\section{LOS CUENTOS, INSTRUMENTO DE ADOCTRINAMIENTO POPULAR}

En los prólogos de las distintas ediciones de sus cuentos, Antonio Trueba explica el sentido de la literatura popular que realiza y predica. Así, en primer lugar, siempre se presenta como un escritor popular, cuya literatura es sencilla y clara para estar al alcance de la inteligencia del pueblo: «El pueblo español es un buen hombre que sabe leer y escribir medianamente y pare usted de contar» - señala en las primeras páginas de los Cuentos populares. Este «buen hombre», que para el escritor encartado debe entender para poder disfrutar y aprender con la lectura, lo contempla como se ve a sí mismo, «con la cabeza muy chica y el corazón muy grande». De esta manera, la literatura emanada de él, que presume coincide con la verdadera mentalidad popular, no puede contener ni altos pensamientos ni imágenes profundas - no puede superar, advierte José $F$. Montesinos, el horizonte mental de ese «buen hombre»-y por eso es, ante todo, puro sentimentalismo y sensiblería. De ahí que para Antonio Trueba sus lectores ideales, como

\footnotetext{
28 Juaristi 1987, 26, 33-39 y 142-148.

29 Mina 1990, 285-292; Molina 2005, 102-105; Portillo 2006, 170 176 y Rubio 2003, 153-158.

30 Al estudio de la vertiente vasca del doble patriotismo en Antonio Trueba hemos dedicado dos trabajos: Pérez Núñez 2020 y "Antonio Trueba ante la revolución de 1868 y la abolición foral: en el tránsito desde la literatura del doble patriotismo a la nacionalidad vasca» (en prensa).
} 
significa en la presentación de sus Cuentos vivos y muertos, son "las gentes de corazón sencillo», es decir, un público predominantemente infantil e ingenuo. Así, sus obras se convirtieron, como subraya Montserrat Amores, en la más típica lectura de familia burguesa acomodada y conservadora, en prototipo de lectura rosa para internados de jovencitas o en sencilla lectura de colegio. ${ }^{31}$

La literatura popular, que para Antonio Trueba tiene su más genuina representación en el cuento, es alternativa y simultáneamente literatura tomada del pueblo y literatura escrita para el pueblo. El autor vizcaíno profesa un verdadero culto romántico por todo lo popular y, particularmente, por sus formas de expresión oral porque - señala en los citados Cuentos - «reflejan en toda su pureza el carácter nacional». Por eso, considera una extraordinaria aportación e inestimable ayuda las recopilaciones de cuentos realizadas por los hermanos Grimm. Sin embargo, no comparte el sistema seguido por ellos de dar a la luz los cuentos más o menos como los habían recogido de boca del pueblo y, en su lugar, él - enfatiza - solo aprovecha su idea capital y su tono, procediendo a su reelaboración para hacerlos verosímiles, conferirles un cierto color literario y, sobre todo, encaminarlos a un fin moral, "porque - subraya en el prólogo de Cuentos de varios colores - un escritor, por humilde que sea, debe aspirar a mucho más que a embobar chiquillos, contándoles absurdos que extravían la razón, en lugar de guiarla por el camino derecho». Pues bien, este afán moralizador acaba haciendo irreconocibles las fuentes folklóricas de sus relatos, convirtiendo su amor por las tradiciones populares en un puro gesto retórico ${ }^{32}$ y permitiendo conocer el espíritu nacional antes de iniciar su búsqueda.

A esta manera particular de hacer literatura popular, Antonio Trueba agrega también un lenguaje muy peculiar. En el ya citado prólogo de los Cuentos populares indica que, de la misma manera que sigue muchos de los cuentos que andan "en boca del pueblo», emplea "la locución popular, el lenguaje plagado de modismos más convencionales que gramaticales y más expresivos que elevados, con los que el pueblo español expresa las ideas más abstractas y explica las cosas más intrincadas». Sin embargo, esta locución se acaba traduciendo en un lenguaje propio, que considera popular, pero que no es más que una sucesión indiscriminada de expresiones coloquiales y castizas, refranes, frases hechas, vocablos populares, diminutivos, etc. que utiliza cualquiera fuera la condición social, época o país. Pues bien, lo que pretende el autor vizcaíno con estos recursos lingüísticos es la cercanía y familiaridad con los lectores, crear efectos humorísticos que suplan la falta de profundidad de las tramas y personajes de sus cuentos y, también, a través de la utilización deliberada de barbarismos o vulgarismos, ridiculizar o ensalzar, según las circunstancias, a determinados personajes, ideas o instituciones. En conclusión, como apunta Montserrat Amores, crea una lengua que llama popular, pero que no es la utilizada por el pueblo. ${ }^{33}$

31 Para el público lector de Antonio Trueba: Amores 1999, 61-63; González-Blanco 1914, 26; Louis-Lande 1905, 321 y 328; Montesinos 1970, 231-234 y Múgica 1914, 12 y 17-18.

32 Juaristi 1987, 141-142; Montesinos 1970, 234-236 y 240.

33 Amores 1999, 85-86; Baquero 1992, $71-72$ y Juaristi 1987, 138-139.
Por lo general, Antonio Trueba escenifica los cuentos, tanto los que toma del pueblo como los que él crea, en entornos conocidos porque es donde se encuentra seguro. El literato vizcaíno está incomodo en el litoral con el horizonte abierto, siente un auténtico pavor a los viajes y era muy receloso con todo lo foráneo y extranjero, para él siempre extraño y desconocido. Profesa un verdadero culto al hogar nativo, es familiarmente casero, apegado al terruño -observa Andrés González-Blanco-. Por eso sus relatos generalmente se inspiran y desarrollan en su tierra natal, el País Vasco y prioritariamente Las Encartaciones vizcaínas, y, ocasionalmente, en la tierra de acogida, Madrid. Pero en ambos casos las tramas normalmente transcurren en lugares recogidos, en pequeños pueblos, en aldeas, y cuentan con cuadros paisajísticos de valles y montañas en los que siempre es primavera, con riachuelos, flores brotando por todas partes, mariposas revoloteando y pájaros cantando. Esta idealización del paisaje rural, sobre todo de Las Encartaciones, ${ }^{34}$ parece deberse a su afición por la evasión romantizada, al pronto abandono de la casa paterna que ocasiona que, cuando Antonio Trueba desde Madrid lo intenta describir para sus narraciones, la imaginación se le desborde. Pero también, todo lo indica, a un intento de retención en la retina de un mundo que inapelablemente se acaba por la transformación industrial y la modernización liberal, y que quiere recordarlo a la manera conservadora tradicionalista siempre como un tiempo mucho mejor.

Pues bien, en esta especie de cartel de agencia de viajes, donde nunca llueve -o lo hace cuando es necesario y en la medida justa - y la naturaleza es tan benévola, es donde Antonio Trueba desarrolla sus cuentos que casi siempre son de color de rosa. Así, sus relatos que, se suelen situar en el hogar familiar - lugar por excelencia-, establo, campo de labranza, camino rural, plaza del pueblo, parroquia, ermita, taberna, mesón, emparrado, etc. y privilegiar los aspectos costumbristas, folklóricos y tradicionales populares, presentan una realidad de absoluta concordia social y de ausencia de conflictos y problemas, en la que impera lo bello, noble, honrado, honesto, generoso, la felicidad doméstica, "los cuadros de familia, más o menos apacibles y sonrosados»-como señala el escritor encartado en el prólogo de su novela Mari-Santa. De la misma manera son los personajes, carentes de profundidad psicológica y, tan virtuosos e inmaculados, que se ruborizan en un capítulo sí y en otro también. En definitiva, Antonio Trueba «no tenía sentidos - significa José F. Montesinos- para lo que no fuera su aldeanito de Nacimiento de cartón, en medio de un valle idílico, que parece también de Nacimiento $-\mathrm{y}$ suele ser también de cartón». ${ }^{35}$

En este mundo feliz también se integra el escritor encartado. En efecto, siempre está presente en sus composiciones bien como narrador, describiendo concienzudamente los escenarios o realizando digresiones para intercalar coplas, seguidillas, etc., bien como un personaje más o interviniendo en la trama a través de los animales que pululan en sus cuentos, pero, sobre todo, como educador. Así,

34 Gómez 1989, 11-12; González-Blanco 1914, 11-13; Louis-Lande 1905, 343-344 y Múgica 1914, 38-40.

35 Peers 1967, 407; Amores 1999, 55-58 y 106; Baquero 1992, 73-74; Juaristi 1987, 137-138; Louis-Lande 1905, 339 y Montesinos 1970,240 y 243. 
si para Antonio Trueba la literatura siempre debe cumplir la máxima horaciana de deleitar enseñando, en la suya el papel que parece protagonizar es el de maestro o cura de pueblo porque, siendo el que mejor se ajusta con la imagen modélica de la vida aldeana, el afán didáctico-moralizador la domina, supeditándose cualquiera otra razón estética o narrativa. De esta manera, a luz de la moral católica conservadora, siempre alecciona al lector en los comportamientos que considera ejemplares y en las actitudes contrarias, que estima deben ser censuradas y castigadas. ${ }^{36}$

\section{Al SERVICIO DE DIOS, LA PATRIA Y LA FAMILIA}

En 1875, en el prólogo a los Cuentos del hogar, Antonio Trueba señalaba que, «sin temor a que se le acusara de vano y soberbio, podía blasonar que acaso era entre sus hijos [de Vizcaya] el que más servicios había prestado con su pluma a la causa de Dios, de la patria y de la familia». No le faltaba razón. Estas tres causas, que, como la Santísima Trinidad, se reducen a una porque tanto la patria como la familia -en expresión reiterada por el narrador encartado- deben ser "como Dios manda», están en el horizonte de sus cuentos populares. Así, pudiendo agregar a ellas, si se quiere, el trabajo, otro de los grandes principios de Antonio Trueba que suele vincular a la familia, tenemos la espina dorsal de las cincuenta y cinco narraciones recogidas en las primeras versiones de Cuentos de color de rosa, Cuentos campesinos, Cuentos populares, Cuentos de vivos y muertos, contados por el pueblo y Cuentos de varios colores, así como algunos poemas seleccionados de El libro de los cantares y El libro de las montañas, que son el objeto de nuestro análisis.

Este estudio centrado, más que en los argumentos y tramas, a nuestro juicio, bastante simplones y pueriles, en las reflexiones, ideas y finalidades morales de los textos, se aborda a partir de la visión maniquea que de la realidad social tiene Antonio Trueba. Así, la ordena, a la manera agustiniana, mediante representaciones del bien y del mal: de una parte, se encuentra todo lo que es como Dios manda o se conforma con los parámetros del catolicismo; y, de otra parte, todo lo que es contrario, contradictorio o se sitúa al margen. "La humanidad es la misma/ — sentencia en Paisaje - /aunque varíe en la forma:/conjunto de ángel y diablo,/ mezcla de luz y de sombra,/ colmena de miel y acíbar,/ ramo de hortigas y rosas». ${ }^{37}$

La religión católica recorre todos los cuentos y muchos de los poemas, pero es el tema central de alguno de ellos, como El Preste Juan de Indias, en el que se afirma que esta confesión «es la única verdadera, grande y salvadora» frente a la judía y musulmana. A la hebrea, que está presente en muchas de sus narraciones a través del insulto asiduamente repetido de iperro judío!, la despacha afirmando que «están condenados a esperar al Mesías hasta la consumación de los siglos, con lo cual están bastante castigados de haber crucificado a Cristo" y a la islámica diciendo algo tan simple como que "Mahoma era un hombre que pasaba por sabio y grande entre sus compatriotas, por aquello de que en

\footnotetext{
36 Amores 1999, 50-51 y 104-105 y Baquero 1992, 74.

37 Trueba 1867, 203-204. En esta visión dicotómica parece seguir los planteamientos de Juan Donoso Cortés, como se recoge en Abellán 1984, 373-376.
}

tierra de ciegos el tuerto es el rey». Además, con la excusa de las Indias, el autor vizcaíno aprovecha para contraponer la acción civilizadora española, llevada a cabo mediante «el hisopo de misioneros católicos cargado de agua bendita», a la nueva británica, realizada con «sus cañones cargados de metralla». ${ }^{38}$

En el cuento Desde la patria al cielo la refutación a los protestantes, a los que califica de «sacrílegos innovadores de la primitiva iglesia», la fundamenta en la ausencia de imágenes de sus templos, que impide que los creyentes, como ocurre en los católicos, puedan demandar consuelos o calmar las tribulaciones, y en el menor respeto y superioridad moral de sus ministros, por no seguir el voto del celibato, que para el escritor encartado contrasta con la dedicación exclusiva a las obligaciones religiosas de la «santa y hermosa figura del párroco [católico] de la aldea». ${ }^{39}$ Pero mucho peor que profesar estas "religiocincillas de tres al cuarto», para Antonio Trueba es el ateísmo porque sus seguidores no creen en nada. Así, le ocurre a Rafael, uno de los personajes de la narración Creo en Dios, sobre el que el autor pregunta: «¿Pero era completamente ateo? ¿no creía en Dios? ¿era materialista?» $Y$ no lo puede entender por el desamparo que ello supone, como subraya en el poema Al anochecer: «iSeñor! cuando en la calma / solemne del crepúsculo / te busca ansiosa el alma / de los mortales míseros, / iqué desdichados fuéramos / si no existieras tú!» Pero, como el autor vizcaíno es bondadoso y, consciente de la envidia que tienen los ateos de los creyentes por no contar con el cielo, ${ }^{40}$ para evitar que el pobre Rafael "pagara muy cara su incredulidad", en el lecho de muerte hace que se confiese y a su hija, que hasta entonces había seguido sus pasos, la acaba convirtiendo al final en «señora mayordoma perpetua de la Virgen».

Con todo, la misma duda que en el ateísmo puede conducir a la creencia, advierte nuestro narrador, en ésta puede conducir al ateísmo. Para él, la forma de evitarlo, de acuerdo con doctrina católica, es mediante el cumplimiento estricto de las virtudes teologales, la fe, la esperanza y la caridad, y, por ello, a lo largo de sus cuentos no deja de catequizar sobre ellas. Así, acerca de la primera, en el último de los cuentos citado, resalta la recompensa que proporciona porque «el Señor me acompaña en todas partes, preside mis dolores y mis alegrías, y, como sabio, justo y omnipotente, me guía, me ampara y me consuela ${ }^{41} \mathrm{o}$, a la manera más del catecismo, en Ofero pregunta el futuro San Cristóbal: «Chiquitos, ¿̇sabéis quién es Dios? ¡Pues no hemos de saber! contestaron los chicos y se pusieron a cantar a coro: Es un Señor infinitamente bueno, sabio, justo, poderoso, principio y fin de todas las cosas». Por su propia definición, la fe exige militancia, es decir, «reconocer - subraya el protagonista de este cuento- que las cosas santas, sean toscas imágenes o maravillosas leyendas, deben creerse y no examinarse». ${ }^{42}$ En Crispín y crispiniano Antonio Trueba hace extensiva esta adhesión a los ritos y creencias religiosas populares que, autorizados por la iglesia, son tildados por los no creyentes

\footnotetext{
38 Trueba $1866 a, 15$ y 17.

39 En esto coincide con Jaime Balmes, como se recoge en Mínguez

40 Trueba 1867,137 y 58 (Creamos).

41 Trueba 1862 b, 188, 192, 375 y $380-381$

42 Trueba 1875,168 y 172.
} 2016, 93 
de supersticiones o fanatismos. ${ }^{43}$ Pero, sobre todo, supone aceptar los designios inescrutables de Dios o, lo que es lo mismo, la resignación cristiana. A la misma y a la esperanza, que la suele enlazar, se refieren muchas páginas de los cuentos y poemas, inspirados - señala Lucien Louis-Lande- en una "moral amable y consoladora». ${ }^{44}$ Así en La felicidad doméstica dice Juan, uno de los personajes, a su mujer después de haber perdido la cosecha: «-No llores, no, que si es Dios justo cuando nos da las mieses, no puede menos de serlo también cuando nos las quita»-y en Bienaventurados los que creen se recoge en consejo materno: «Tal vez encuentres, hijo/ de mis entrañas,/más espinas que flores/ en tu jornada;/ pero, hijo mío,/ piensa que están las palmas/ tras el martirio!».45 También es el leitmotiv de la narración corta Mari-Santa, en la que esta abnegada y caritativa bilbaína, tras la muerte de su hijo de tan solo de tres años, no encuentra consuelo y se considera desamparada por Dios, hasta que una visión le muestra que de haber vivido habría acabado ajusticiado por malvado, y, por eso, «prosternada a los pies del Crucificado exclama: Gracias, Señor, porque llevasteis a vuestro seno a mi hijo antes que fuese indigno de él». ${ }^{46}$ En definitiva, Antonio Trueba recurre con mucha reiteración a la resignación cristiana, no solo por busque la paciente aceptación de las adversidades e infortunios, sino también de la situación social que a cada uno le ha correspondido.

Entre los sacramentos, de obligado cumplimiento, el escritor encartado resalta la eucaristía por su cotidianidad y por la interlocución directa del creyente con Dios. De esta manera, casi no hay un cuento en que no se celebre una misa o en el que alguno de sus personajes - particularmente, mujeres - acuda a la iglesia a rezar el rosario o simplemente a rezar, a realizar una plegaria o dar gracias a Dios, a la Virgen o a un santo, a poner flores en un altar, etc. Además, habitualmente suelen acudir con alegría y emoción porque la devoción sirve para fortalecer la fe, la confianza en Dios y la esperanza. Con la esperanza en el reino de los cielos Antonio Trueba, siguiendo la ortodoxia católica, intenta compensar sobre todo aquellos a los que la vida no les ha tratado muy bien. ${ }^{47}$ Así, en Los borrachos, Rosa, mujer de un marido alcohólico y maltratador, acude llorosa a la iglesia buscando consuelo: "Un corazón lleno de fe y un templo alumbrado solo por la lámpara del sagrario, triunfan al mayor de los dolores. Cuando Rosa salió de la iglesia no había ya lágrimas en los ojos, porque había resignación en su alma y esperanza en el corazón». Con eso se tiene que contentar porque su vida no cambia. Pero, a pesar de ello, en el lecho de muerte está muy contenta: «-Hija mía, dice a la niña sin poder contener las lágrimas, yo voy a ser más feliz que vosotros. ¿Por qué, madrecita? le pregunta la niña con alegría, creyendo que su madre habla de felicidades mundanas. -Porque voy a ir al cielo». ${ }^{48}$

43 Trueba $1866 \mathrm{~b}, 223$. En esta aceptación de las prácticas religiosas populares sigue la doctrina de la Iglesia católica (Ref. Callahan 1989, 226-230).

44 Louis-Lande 1905, 336.

45 Trueba 1862 c, 125 y $1862 a, 77$.

46 Trueba 1866b, 63.

47 En este apartado parece seguir el pensamiento de Antonio María Claret, arzobispo de Santiago de Cuba y confesor de Isabel II (Ref. Mínguez 2016, 100).

48 Trueba 1862 c, 261 y 271.
Al final siempre queda la felicidad celestial. Por eso, en los cuentos de Antonio Trueba la muerte siempre es bien recibida, con alegría y regocijo, y sus cielos siempre están llenos de gente humilde del pueblo. En la narración ad hoc titulada La portería del cielo, San Pedro le dice al recién llegado tío Paciencia, un pobre zapatero remendón de Madrid:

- Hombre, iqué bobo es usted! ¿No ha leído usted en la Sagrada Escritura que más fácil es que entre un camello por el ojo de una aguja que un rico en el cielo? -No, señor, porque como no sé escuela... - Pues crea usted que es el evangelio. Zapateros. herreros, labradores, mendigos, gentes en fin hartas de trabajar y padecer y ayunar, llegan aquí a todas horas y no tenemos por novedad su llegada; pero se pasan siglos enteros sin que le veamos el pelo a un señorón como el que ha venido hoy, y cuando viene alguno echamos la casa por la ventana. ${ }^{49}$

Aunque dominan aquéllos, si vemos los cuentos en su conjunto, la entrada en los cielos de éste y otros como él, de los económica y socialmente bien posicionados, no es tan excepcional. Así la figura del hacendado o rico paternalista, filántropo y altruista se repite en las narraciones de Antonio Trueba. Todo indica que quiere suplir el demérito, que a efectos celestiales supone la riqueza, con la caridad. Con todo es un sentimiento que generaliza a todos los católicos, principalmente a los vascos, hasta el punto que «las madres - subraya - enseñan a los hijos que Dios suele tomar la figura de pobre para recompensar o castigar al que los acogen bien o mal». ${ }^{50}$ Sin embargo, la mejor forma que escritor vizcaíno ejemplifica esta virtud teologal, a la que se refiere con gran asiduidad como una acción muy meritoria a los ojos de Dios, es a través del reparto de la riqueza de los que tienen. Hay dos casos, aunque un tanto extremos, que lo reflejan muy bien. Uno es el de Santiago de La resurrección del alma, rico indiano que lleva una vida de perdición en América hasta el agotamiento y el hastío, del que logra salir gracias al retorno a la aldea natal, a la religión y a su bondadosa hermanastra, con la que acaba casándose, así como "con los pobres», a los que no solo "proporciona pan y trabajo", sino que les convierte en caseros. ${ }^{51}$ Otro de los ejemplos es el de Mateo del cuento De patas en el infierno, patrón rico y generoso que, por retrasar permanentemente su matrimonio con la encantadora Teresa a la realización de obras de caridad y a la finalización de la construcción de un hospital y una iglesia, Dios le envía al purgatorio; al final, un beso de ella le devuelve a la vida y seguidamente se casan. ${ }^{52}$

Con estos y otros casos similares lo que también busca Antonio Trueba es transmitir el respeto debido a la propiedad y a la jerarquía social. Es así, hasta el punto de brillar por su ausencia los ricos no caritativos. Solo hemos encontrado el caso del rico avariento de Navalcarnero del cuento El tío Miserias, que podría ser considerado un anti-modelo. Pero, sobre todo, para el narrador vizcaíno lo son, además de los no creyentes o creyentes de otras confesiones ya señalados, los que no cumplen con los deberes religiosos, los ociosos, los corruptos y malversadores públicos, los artistas y escritores depravados, las adivinadoras, embaucadoras

\footnotetext{
49 Trueba $1866 \mathrm{~b}, 34$.

50 Trueba 1870, 107; y Paisaje en 1862a, 200.

51 Trueba 1862b, 17-85.

52 Trueba $1875,213-238$.
} 
y curanderos, los alcohólicos, infieles y maltratadores, en definitiva, como señala en La resurrección del alma, los que practican «amores vergonzosos, el juego, los espectáculos sangrientos, el lujo, los banquetes, todas esas cosas que constituyen la dicha de las almas vulgares». ${ }^{53}$ Casi todos ellos, de acuerdo con lo que Antonio Trueba escribe en sus cuentos, son producto de las tentaciones o están al servicio del diablo, y la única forma de hacerles frente, y evitar acabando en el infierno, es el cumplimiento ya significado de la doctrina y de las prácticas religiosas de la iglesia católica.

A ellas se adecúa la muy venerada institución familiar de nuestro narrador. El cuento Juan Palomo termina con la muerte del personaje que le da título, un soltero empedernido, exclamando «iBendita sea la familia!». Es la expresión de la adhesión al final de sus días a esta institución después del alegato a su favor realizado por Antonio Trueba a lo largo de sus páginas. En ellas afirma que la familia es una organización dispuesta por Dios y, por lo tanto, necesaria para el individuo y la sociedad. ${ }^{54}$ La define como una especie de cuerpo fundado en el amor y el matrimonio santos - al decirlo se ruboriza - ${ }^{55}$ para compartir alegrías y tristezas y para el reparto de las cargas vitales: «se unirán - se señala en la narración citada - que ni una pareja de bueyes pueda separarlos, y así tirarán para adelante llevando la carga a medias». Pero, para Antonio Trueba, la familia es algo más, es la expresión de la continuidad social y, también, el ámbito donde se logra la verdadera felicidad. Así, suele asentar a la familia en la casa heredada, que permite vincular a padres y a hijos en una cadena ininterrumpida de generaciones: «Es necesario - afirma en el cuento El judas en casa- que la casería de Echederra continúe perteneciendo a la familia que la ha poseído siempre». ${ }^{56}$ Para nuestro narrador es casi un imperativo categórico porque, a la acumulación de esfuerzos y trabajos realizados a lo largo del tiempo, se suma la memoria y la tradición de la familia. Pues bien, sobre estas "hondas raíces» erige el hogar familiar, una especie de espacio de protección, sentimientos, recuerdos y afectos que produce la felicidad doméstica que, como recoge el cuento con el mismo título, La felicidad doméstica, para Antonio Trueba es la auténtica felicidad, que suple todas las carencias. ${ }^{57}$

\footnotetext{
53 Trueba 1862b, 42; y La vida y la muerte en 1862a, 217-223.

54 Trueba 1862 b, 362 y 297 . En su visión sobre la familia hay un estricto seguimiento de la doctrina de la Iglesia católica (al respecto, Mínguez 2016, 21, 82 y 97).

55 Como se puede ver en su descripción de la relación íntima de matrimonio de Antonio y Feliciana, dos de los protagonistas del mismo cuento (Trueba 1862b, 303): «Antonio que estaba inclinado hacía e lecho en que reposaba su mujer, fresca, sonrosada, hermosa, iluminada por la felicidad que dan el amor santo y la conciencia tranquila, dejó caer una lágrima de regocijo sobre el rostro de Feliciana. Y la noble y enamorada esposa alzó los brazos y enlazó el cuello de su marido, mezclando sus lágrimas de felicidad con las de Antonio. Feliciana y Antonio eran rústicos, eran ignorantes, apenas sabían que el mundo se extendía más allá de las últimas montañas que divisaban sus ojos; pero sabían, sin haberlas aprendido, todas esas cosas delicadas, y puras, y nobles y santas que nosotros, los que leemos o componemos libros, creemos haber aprendido en unos cuantos pliegos de papel. ¡Cómo era posible que Dios hubiera concedido a una combinación de signos el privilegio exclusivo de revelar los sentimientos más bellos y santos!».

56 Trueba 1862b, 256.

57 Trueba 1862 c, 132.
}

Nuestro narrador nos presenta una familia muy tradicional, al igual que lo son los papeles que confiere a la mujer y al hombre. De la primera no tiene duda alguna cuál es su modelo, «el pintado por Fernán Caballero con toda la magia de su admirable pincel, la mujer buena, honrada, santa, en sus dos fases de virgen y madre, de hija y esposa». La primera fase es inexcusable para la segunda. Así lo establece en el cuento La enamorada, en el que, además de asumir la anterior afirmación, él aparece como un personaje más que regala las obras completas de aquél a Soledad para su consuelo y el de sus hermanos porque, su deshonra por un hombre casado, no solo la estigmatiza y la condena a la soltería, sino supone un auténtico oprobio para el apeIlido familiar, hasta el punto de acabar provocando el fallecimiento de la madre. ${ }^{58}$ Algo parecido le ocurre a María, protagonista del poema Una romería, por no atender las advertencias maternas:

Esas vírgenes que fueron/tus compañeras queridas, /felices con su inocencia/ bajan a la romería, /y tú avergonzada escondes/ la frente descolorida / y ni a decirles te atreves:/ "Adiós, compañeras mías!» / [...] que hoy justamente se cumple / una fatal profecía, que hoy hace un año te dije / presintiendo tu desdicha: / «Acaso llores otro año» / cuando el tamboril, oh niña, / «tan-taran$\tan -\tan »$, resuene,/ "resuene en la romería!». ${ }^{59}$

A partir de aquí, manteniéndose "virgen sin mancilla» como comienza el poema que no puede titularse de otra manera que Virginidad, ${ }^{60}$ para Antonio Trueba una «mujer como Dios manda» debe ser instruida para realizar las tareas del hogar y gobernar la casa «con fundamento", educar y cuidar con amor maternal a los hijos y tranquilizar, complacer y ayudar al marido. De esta manera entiende Rosa, personaje del cuento Desde la patria al cielo, el amor:

Aprender todo lo que saben mi madre y la tuya para hacer lo que ellas hacen; gobernar bien la casa cuando nos casemos; querer, cuidar y enseñar a nuestros hijos, si Dios nos los da; trabajar a tu lado para que el trabajo te pese menos; alegrarme cuando estés alegre, entristecerme cuando estés triste, y morirme de pena si tú te mueres. Esto es, Pedro, esto es lo que yo tenía por amor. $^{61}$

Más aún, solo en este amor, se afirma en Creo en Dios, las mujeres encuentran las dichas del mundo.

Pero, por si esta anulación de las mujeres como personas resultara insuficiente, el autor vizcaíno no deja de repetir por activa y por pasiva su «debilidad en cuerpo y alma». Por eso considera necesitan del sostén y protección de los hombres, censurando el maltrato infringido por alguno de éstos porque - argumenta en Las vecinas - «las mujeres son niños grandecitos y Dios ha creado a los hombres para

58 Trueba $1875,180$.

59 Trueba 1862a, 116-117.

60 Trueba 1867, 128: «En tí, virgen sin mancilla,/ pensaba yo esta mañana/ vagando en las arboledas/ cuando las aves alzaban/ al que hace brotar las flores/ el canto de la alborada,/ y holgué de no haber tocado/ jamás tu mejilla casta/ al oír a un pastorcillo/ que cantaba en la montaña:/ "Rosas en la cara tienes/ y no me atrevo a tocarlas/ porque el olor de las rosas/ si se las toca, se marcha"».

61 Trueba $1862 \mathrm{~b}, 153$. 
amparar a los niños, que no para maltratarlos».62 También debido a su debilidad de carácter para Antonio Trueba las mujeres son más propensas a verse tentadas por el diablo: «Siempre que vais - sermonea a las madres en El ángel y el diablo- a un baile, a un café o una tertulia, dejando a vuestros chiquitines en casa, el diablo se mete en ella cuando vosotras abrís la puerta para salir». Y por eso, para evitar este tipo de comportamientos, les aconseja que no hermoseen sus personas con frívolos adornos y afeen su alma con pasatiempos más frívolos aún. ${ }^{63}$

Pues bien, por esta mayor facilidad que tiene el diablo para meterse en su cuerpo, ${ }^{64}$ debido - todo parece indicarlo en nuestro autor - a la responsabilidad agravada en el pecado original por Eva, las mujeres precisan una salvaguarda divina superior y, de ahí, que el narrador encartado les haga rezar, acudir a la iglesia cotidianamente e implorar, sobre todo, a la Virgen María para redimir su culpa y acercarse a sus virtudes como modelo de madre. ${ }^{65}$ Así, en el poema Plegaria lo solicita una progenitora para su hija: "Inmaculada María /que ves el inmenso amor,/ el inmenso amor de padre/ que ha atesorado en mí Dios;/ Inmaculada María,/ da tu pureza y candor/ á la inocente y hermosa/ hija de mi corazón!». ${ }^{66}$

Por lo que vamos viendo, el modelo de mujer que representa Antonio Trueba se distancia algo del de «el ángel de hogar», arquetipo de la feminidad de la cultura liberal hegemónico desde mediados del XIX, y se acerca al de mujer católica, de acuerdo con las pautas más antiliberales del obispo catalán Antonio María Claret y, en parte, con las de Fernán Caballero. Así la mujer del autor vizcaíno responde al ideal de mujer doméstica, es decir, laboriosa y cumplidora con las tareas del hogar y con las obligaciones familiares, abnegada con los hijos y siempre supeditada a los deseos y a la autoridad del marido, incluso aunque este tuviera que

62 Trueba 1875,6 y 8 . Censura el maltrato, pero estima que no se debe ir más allá de una simple reprobación. El diálogo que recoge en este cuento no puede ser más elocuente: «iCalle usted por Dios, señora! ¡Buenas pulgas tiene mi pariente para eso! Puede que me reventara de una patada - iAve María! ¿Le había de pegar a usted, señora? - iAy, hija, bien se conoce que no sabe usted de la misa la media! Mañana hará ocho días me puso el cuerpo a golpes más negro que mi vestido - ¡El Señor nos asista! ¡Jesús, qué pícaro de hombre! Y no hay un presidio - Señora, poco a poco, que mi marido no ha robado nada a nadie! Él tiene mala cabeza, eso sí, y se deja llevar de otros calaveras, pero hombre de bien a carta cabal, lo es».

63 Trueba 1866 b, 11 y 1870, 54 En la consideración de la triada novela-teatro-baile como una invención del demonio sigue los planteamientos de la Iglesia católica y particularmente los de Antonio María Claret (Ref. Mínguez 2016, 95-98).

64 Así lo intenta aseverar en El tío Miserias (Trueba 1866b, $267-$ 268): "Sabido es con cuánta facilidad se mete el diablo en el cuerpo de las mujeres. Y a propósito de esto voy a dar a conocer un dato estadístico muy curioso. En Zalla, que está en las Encartaciones de Vizcaya, hay un santuario que lleva el nombre de San Pedro de Zariquete, y adonde desde tiempo inmemorial acuden los que tienen el diablo en el cuerpo para librarse de tan peligroso huésped. Yo me he entretenido en examinar los libros en que se consignan el nombre y circunstancias de los poseídos, y de los datos que he trasladado a mi cartera, resulta que por cada hombre que acude a San Pedro de Zariquete con el diablo en el cuerpo, acuden veinte mujeres, y que generalmente se las ha entrado a éstas por la boca».

65 Tiene planteamientos muy cercanos a los de Joaquín Roca y Cornet (Mujeres de la Biblia, 1850), que explica con muchísimo acierto Mínguez 2016, 133-177.

66 Trueba $1867,60$. imponerse mediante el uso de la fuerza. Además, es fervientemente religiosa, pero conforme a los cánones antiguos, porque mantiene la concepción de su naturaleza corrompida y potencialmente tentadora — de ahí que la aleje de la coquetería, la moda y los espacios sociabilidad burguesay no la confiere el rol de «la mujer fuerte» neocatólica, cuya superioridad moral sobre el varón le hace participar de manera notable en la empresa de la recatolización de la sociedad española. ${ }^{67}$

En consonancia con el modelo de mujer del literato vizcaíno resulta totalmente coherente la afirmación que realiza en La madrastra: "Dios ha impuesto al hombre el deber de amparar y de servir de apoyo a la mujer desamparada y débil por naturaleza».68 $\mathrm{A}$ esta protección, que es extensiva a los hijos y como contrapartida exige la sumisión, el hombre debe sumar la obligación del mantenimiento de la familia y la primordial tarea de su tutela y buen gobierno, en la que debe ser justo, indulgente y generoso, pero con la autoridad suficiente. Debe ser así porque de él depende el mantenimiento del honor familiar o, como advierte en $L a$ enamorada, "la conservación sin mancha de la honra de la casa», "el apellido que llevan». ${ }^{69}$ Estas mayores obligaciones, que hacen de la familia una organización plenamente patriarcal, derivan para Antonio Trueba de la superioridad y mayor capacidad de los hombres. Y de esta autosuficiencia más alta se infiere que precisan una menor ayuda divina y de aquellas cargas superiores una necesidad más grande de esparcimiento. Por eso, en las tramas de los cuentos acuden menos a la iglesia que las mujeres y, como señala en Los borrachos, si para éstas «no hay mayor diversión que el cuidado de la casa y el amor a la familia», ellos necesitan charlar con otros hombres, jugar un mus, echar un cigarro o una pipada y «beber para abrigar el estómago y cobrar ánimo para el trabajo, no para emborracharse». ${ }^{70}$

De esta manera, al igual que ocurre con la mujer, el hombre que construye nuestro autor es un hombre católico, que sigue muy de cerca las directrices del padre Antonio María Claret. Así, es alguien que, como explica María Cruz Romeo, rechaza las lecturas perniciosas y no frecuenta los espacios de sociabilidad masculina (tabernas, cafés, teatros, bailes) porque, como ya hemos visto, para Antonio Trueba son lugares de perdición. Es aquel que tiene en el centro de su vida a la familia, como ocupación y diversión, y como principal actividad el trabajo para el mantenimiento y desarrollo del patrimonio familiar y ejemplo para los hijos. En definitiva, debe ser un buen padre y esposo, cumplidor con los deberes religiosos, justo en el ejercicio de su autoridad, fiel y leal a su esposa y con una vida morigerada. ${ }^{71}$

De ahí que el autor encartado censure el alcoholismo, que ve muy extendido en el País Vasco, pero quizás con más energía la ociosidad, - «la madre de todos los vicios»afirma en Juan Palomo. Así, muchas de las páginas de los cuentos constituyen un verdadero alegato en favor del

67 Andreu 2012, 18-21; Mínguez 2018, 27-45 y Romeo 2017, 95-101.

68 Trueba $1862 \mathrm{~b}, 101$.

69 Trueba 1875, 184. Algo que subraya Andreu, 2017, 33, como un principio inexcusable: «El honor que se vincula al de toda la familia. La pérdida de la virtud resulta inaceptable».

70 Trueba 1862 c, 249 y 284

71 Romeo 2018, 84-88. 
trabajo, hasta el punto de declararlo santo y otorgarle primacía a la devoción: «Santo es rezar, pero por la devoción no se debe dejar la obligación» - dice el cura de ese cuento-.$-^{72}$ En esta misma línea, otro cura, el de La felicidad doméstica, en su sermón de la misa solemne «procura fortalecer en el corazón de los labradores el amor a los campos y al trabajo», arrancando "más de una vez lágrimas de consuelo en el auditorio». ${ }^{73}$

Antonio Trueba reprueba aquellas doctrinas o propuestas sociales que cuestionan el valor del trabajo (así lo hace en La compota $)^{74} \mathrm{y}$, desde una perspectiva conservadora, junto al esfuerzo, la constancia, la diligencia, el cumplimiento de la obligación y el ahorro, lo vincula a la respetabilidad y dignidad personal: "sin trabajo no hay honra». ${ }^{75}$ Por eso en el trabajo y los otros valores reseñados, supliendo a las carencias materiales, hace descansar el orden y el progreso personal y social. De esta manera, madrugando y acostándose pronto todos los días, como apunta en Las siembras y las cosechas, las familias prosperan porque siembran y recolectan durante muchos años y con ellas las aldeas que forman. ${ }^{76}$

Así parece que es, si atendemos a las descripciones que Antonio Trueba realiza de éstas, fundamentalmente de las sitas en Las Encartaciones vizcaínas. Así, constituidas por unas cuantas caserías alrededor de una iglesia y en las que nunca falta un arroyo cercano, sus moradores siempre están cantando y riendo alegremente porque viven un medio cuasi-paradisiaco, donde los prados están siempre verdes, los cultivos de los huertos son pródigos, los árboles están cargados de fruta, las flores brotan por todas partes y los pájaros no dejan de entonar sus cánticos. Esta realidad tan bucólica para nuestro narrador es producto de la santa conjunción armónica del templo, el hogar y la naturaleza. Así lo afirma en La resurrección del alma y subraya que allí (en Las Encartaciones y, por extensión, en el País Vasco) «siempre se confunden armónicamente el toque de la campana, el nombre de ipadre! ihijo! ihermano! y el canto del ruiseñor o la malviz».

Esta «consoladora trinidad», como así la llama, cuando no irurac-bat, ${ }^{77}$ es de la que Antonio Trueba hace derivar el amor a la tierra donde uno ha nacido, que es como «una segunda madre y se la debe querer como a la primera». Por eso considera que «el amor a la tierra natal es la condición natural del hombre». ${ }^{78}$ Es así porque es en este espacio donde la familia alcanza la verdadera felicidad doméstica, compartiendo la vida con sus convecinos o compatriotas de la aldea o la patria chica. Así, ésta, en el universo aldeano de nuestro narrador, es una comunidad que ampara y da cobijo a las familias en las situaciones de infortunio y, por eso, en La enamorada el pueblo encabezado por el cura párroco acoge con compasión y amor a Soledad, deshonrada por un hombre casado de Bilbao. ${ }^{79}$ También los vecinos son condolientes y fraternales con la familia que pierde a uno de sus miembros:

\footnotetext{
72 Trueba 1862 b, 305 y 307.

73 Trueba 1862 c, 164

74 Trueba 1875, 303.

5 El alboguero de Astola en Trueba 1867, 152.

6 Trueba 1862c, 44.

Trueba 1862b, 39.

Amor a la patria en Trueba 1864, 42.

Trueba 1875, 211-212.
}

El señor cura — de Alzola (Elgóibar) de Recuerdos de una aldea- se vuelve al auditorio y con la voz temblorosa dice: - Ya sabéis que ayer entregó su alma al señor nuestra convecina Fulana. Esta tarde a la seis se dará sepultura al cadáver, y espero que acudiréis todos a ofrecer el último tributo a la que ha vivido y ha muerto entre nosotros participando de nuestras alegrías y nuestras penas. [...] A las cinco de la tarde las campanas de Alzola empezaron a tocar a muerto. [...] Todos los campesinos del valle y los caseríos dispersos en las altas montañas que a éste dominan fueron acudiendo a la casa mortuoria vestidos de luto y dando señales de sincero dolor. ${ }^{80}$

Igualmente, la aldea es solidaria con sus vecinos a través de la costumbre de la «ayuda mutua». Tal como se constata en Desde la patria al cielo, cuando, de nuevo,

el cura párroco se vuelve desde el altar a sus feligreses y les dice: - Ya sabéis que Fulano está enfermo y sus heredades sin sembrar [...] El domingo siguiente oyen misa los habitantes del valle al despuntar el sol [...] y enseguida se trasladan pobres y ricos, chicos y grandes, mujeres y hombres a los campos del vecino enfermo, que quedan sembrados cuando el sol desaparece tras las montañas. ${ }^{81}$

Como vamos viendo, la aldea complementa a la familia en la adversidad, pero también en la alegría. Como ocurre en las festividades y romerías tradicionales que reúnen a todos los vecinos, igualmente sin distinción alguna y con la presencia de las autoridades civil y religiosa, en los oficios religiosos, en los juegos (de bolos, pelota o barra) y en los bailes hasta que cuando anochece - se recuerda en La enamorada- «suena el toque de oración, el tamboril calla y se suspende el baile; los hombres se descubren la cabeza, y mujeres y hombres quedan inmóviles, rezando en silencio las avemarías». ${ }^{82}$

$\mathrm{Si}$ a las anteriores reuniones sumamos las de las celebraciones religiosas ya contempladas anteriormente y los otros actos vitales fundamentales, apuntamos al cura párroco como una figura nuclear de la aldea. Esta es la razón por la que, salvo el caso del cuento la Gramática parda, donde se presenta a un sacerdote glotón y vanidoso, ${ }^{83}$ los curas de Antonio Trueba son siempre piadosos, caritativos, bondadosos, afables, sabios y con un cierto halo de santidad. Así son los retratos de los párrocos de Alzola, que suple al maestro de primeras letras de que carece la aldea, y, sobre todo, el de su aldea natal de Montellano, que se alarma y tiene que cambiar de vida para disipar el rumor de que es santo y posee el don de hacer milagros. ${ }^{84}$ Muy cercanos a ellos se encuentran los alcaldes, que los presenta como unos vecinos más, justos, íntegros, paternalistas, como la expresión del buen gobierno, pero siempre muy subordinados a la religión y a la moral católica.

Más aún lo está el maestro porque Antonio Trueba, como buen conservador, no es partidario de que el pueblo tenga una formación profunda, ya que piensa que la razón puede

\footnotetext{
80 Trueba $1864,160-161$.

81 Trueba 1862 b, 159.

82 Trueba 1875, 195.

83 Ibídem, 285-294.

84 Recuerdos de una aldea y El cura de Montellano en Trueba
} $1864,159-160$ y 221. 
extraviar la imaginación y hacer que no se dirija por buen camino. Así le ocurre a Pedro en Desde la patria al cielo a quien, después de pasar cuatro años leyendo los libros de la biblioteca del indiano, se le ofusca la cabeza y amarga el alma. Tras recorrer medio mundo y apesadumbrarse aún más, el narrador vizcaíno le redime a través de la religión, la familia y la aldea, no sin antes hacerle despotricar contra el intelectualismo. De esta manera, como «los libros son como escopetas, que aún que sean útiles para muchos, son para algunos peligrosos», según dice el cura de este cuento, ${ }^{85}$ la gente de pueblo para Antonio Trueba necesita ser orientada - subraya en La resurrección del alma - para "comprender la hermosura de Dios, del arte y de la naturaleza, para apreciar en todo su valor los sentimientos elevados, para separar lo delicado de lo grosero, y para distinguir entre el mal y el bien, y entre lo justo y lo injusto». ${ }^{86}$ En definitiva, la educación siempre tiene que estar supeditada a la religión y bajo su control, y la formación adquirida debe limitarse a poder leer los libros de sus pequeñas bibliotecas familiares (en las que, junto a libros religiosos, Antonio Trueba siempre coloca El Quijote y los Fueros de Vizcaya) o de aquellas obras recomendadas por resultar moralmente beneficiosas, como, entre otras, las Fernán Caballero, El alma desterrada, leyenda de Ana María, El genio del cristianismo de FrançoisRené de Chateaubriand y, por supuesto, las suyas.

Las buenas costumbres y tradiciones, el buen gobierno civil y religioso y una sabia educación católica hacen que la aldea, al ser como Dios manda, sea considerada por los vecinos de Juan Palomo "la mejor del mundo», que no pudieran "comprender que fuera de aquel nido de ramas y flores existiera felicidad $»{ }^{87}$ Pues bien, agregando los rasgos más específicos de las Vascongadas para Antonio Trueba su realidad local llega al paroxismo. Así, asentándose en los mitos fueristas fundamentales (independencia originaria, monoteísmo primitivo, el igualitarismo y disfrute ancestral de las libertades, la pureza de sangre, etc.), recogidos principalmente en la narración de Jaun Zuria y contemplados en muchos poemas de El libro de las montañas, ${ }^{88}$ presenta a los vascos como un pueblo ejemplar: profundamente fervientes y religiosos; amantes de la familia y de su tierra; fieles a las buenas costumbres y tradiciones; humildes, generosos, caritativos y de trato igualitario; leales, honrados y valerosos; emprendedores, diligentes y trabajadores; respetuosos con la propiedad y con las jerarquías sociales....También, para nuestro narrador, los vascos son modélicos en la superación de sus propias contradicciones: la guerra carlista, «la lucha del euskera contra el euskera, del hermano contra el hermano», con el silencio y olvido que facilitan la religión y la permanencia en el disfrute de los fueros, constitución tan

\section{Trueba 1862 b, 129-209.}

86 Ibídem, 59.

87 Ibídem, 328

88 Valga de ejemplo el siguiente fragmento de Arrigorriaga (Trueba 1867, 235-236): Cuando el venerable aitona /narra en nuestras caserías / en las veladas de invierno /estas memorias queridas / sentado en el ancho escaño /donde su frente ilumina / la luz del hogar doméstico / y su corazón se agita / a impulso del amor santo / de la patria y la familia, / añade, hacia Arrigorriaga / dirigiendo mano y vista: / «Allí Ordoño el sueño eterno / duerme a la sombra bendita / del templo que levantaron / los guerreros de Zuría / para recordar que vencen / los que por la patria lidian, / y en aquel glorioso valle / la libertad vizcaína / ni nunca vencida ha sido / ni nunca será vencida!». ejemplar como el pueblo que la posee; la expulsión de sus propios hijos al tener que migrar a América con su retorno como indianos filántropos, altruistas y paternalistas. ${ }^{89}$

El carácter arcádico de los pueblos vascongados y de las aldeas en general se reafirma en Antonio Trueba a través su mirada a las ciudades. En Desde Madrid al cielo es donde mejor se recoge esta comparación. Este cuento, que tiene algunas connotaciones biográficas, tiene como protagonista a Ángel, chaval inocente de doce años natural de una aldea vizcaína, enviado a Madrid para formarse en la casa de un tío rico banquero. El shock que sufre es brutal al tener que enfrentarse: primero, a una ciudad bulliciosa, apresurada, sucia, descuidada, con un clima muy frío y seco, y sin espacios verdes; segundo, a sus tíos, que están peleándose permanentemente y no le ofrecen cariño alguno; tercero, a sus compañeros de oficina que, con vidas muy disipadas, le maltratan continuamente. Al final, es tal la añoranza que tiene de la familia y de la aldea, que acaba muriendo de nostalgia. ${ }^{90}$

De esta manera la ciudad de Madrid, pero también puede ser Bilbao o las principales capitales europeas que recorre Pedro en Desde la patria al cielo, son la expresión de la corrupción de las costumbres y de la ruptura del orden y de la comunidad tradicional. Por eso, siendo la antítesis de la aldea dichosa, no es aquélla, sino ésta, donde Antonio Trueba como Fernán Caballero encuentra en su pureza la esencia nacional, sobre la que levanta la patria grande: «en torno de diez mil campanarios, quince millones de campesinos que riegan y fecundan con el sudor de su frente los campos de donde procede aquel oro [trigo] [...] que viene a henchir el Tesoro público [...] y aquellos frutos y aquellos mancebos [...] que vienen a servir a la patria». Así, lo plantea en 1862, en el prólogo a la segunda edición de Cuentos campesinos y en cuyo apéndice acoge una propuesta de nacionalización de España desde abajo, desde los pueblos:

Sabido es que - arguye- el amor al hogar y a la familia es el más fecundo manantial de patriotismo. La localidad en que se vive y el vecindario que la puebla constituyen un segundo hogar y una segunda familia. Engrandézcase, glorifíquese, embellézcase la localidad con la poesía de la historia, que es la poesía de los recuerdos y los moradores la amarán. [...] Así todos los pueblos tendrían sus anales, que, andando el tiempo, serán de una utilidad inmensa para la historia particular del pueblo y para la general de la nación. ${ }^{91}$

Un ejemplo de ello, de la construcción de la historia nacional a través de los recuerdos populares, se puede ver en la guerra de la independencia, cuya memoria está presente en distintos cuentos, como en El más listo de Carmona. En éste aparece un personaje que se llama el tío Bailén porque su mayor dicha es contar la batalla del mismo

89 Estos rasgos están presentes en muchos de sus cuentos, pero particularmente en Trueba, Jaun Zuria y La enamorada $(1875,201)$. Su conversión en arquetipo fuerista en Molina 2005, 92.

90 Trueba 1866a, 101-172. En Amor a la patria (Trueba 1864, 47-48) el escritor encartado desdramatiza la realidad de Madrid, pero insiste en el padecimiento de la afección de la nostalgia porque en ella todo el mundo es forastero y todo el mundo habla de su tierra. A esta inclinación a la «dulce melancolía» también se refiere Louis-Lande 1905, 326-327.

91 Trueba 1862 c, 7 y 382 y Amores 1999, 32. 
nombre, en la que quedó ciego a resultas de las heridas sufridas, y lo hace («con los ojos del alma») «con tan vivos colores y tal entusiasmo, que nuestro corazón late violentamente y las lágrimas escaldan nuestra mejilla». El fuerte sentimiento nacional («el santo amor a la patria») ${ }^{92}$ que aquí trasmite alcanza su cota más alta en el poema La vida de Juan Soldado. En él recoge una narración muy conservadora y católica de esta guerra, en la que, retratados los franceses como malhechores, despiadados, crueles y, por supuesto, ateos y anticatólicos, la lucha de los españoles siempre heroica es por el rey y la patria, pero sobre todo por la religión. Así, otorgándole el carácter de cruzada, presenta al enfrentamiento con los galos como una segunda reconquista que, como la primera, deja grandes nombres y lugares para la memoria nacional: el dos de mayo, Bailén, Talavera, Zaragoza y la Virgen del Pilar, Arapiles, Vitoria, San Marcial, Castaños, Palafox, El Empecinado, Mina, etc. ${ }^{93}$

Por lo tanto, a la hora de interpretar este conflicto, como a la nación y a la historia de España, Antonio Trueba sigue muy de cerca la perspectiva moderada, claramente retrospectiva y tradicional, con el único fin de afirmar la Monarquía isabelina. Así, la historia nacional se deviene en una historia de la monarquía identificada con el Estado y la consecución de la unidad religiosa y política. ${ }^{94} \mathrm{~A}$ este respecto, la visión que, sobre la nación, le confiere a la reina nuestro narrador en La ambición a Isabel II no puede ser más elocuente: «-¿Pues qué ven otras reinas? - Por ejemplo, la reina de España ve una serie de grandes y gloriosos reyes que se llaman Recaredo, Pelayo, san Fernando, Alfonso el Sabio, Isabel la Católica, Fernando el Católico, Carlos V, Felipe II, Carlos III... y esos reyes tuvieron su sangre y se sentaron en su trono y amaron y engrandecieron al pueblo que ella ama y engrandece». ${ }^{95}$

En otros cuentos y poemas incide en alguno de los hitos de este dilatado recorrido histórico, como la reconquista y los grandes mitos de Covadonga, Pelayo y El Cid, que le sirven para identificar a España con el catolicismo: «Madre España, madre España, / tú que eres cristiana pura / y única nación del mundo / que en serlo su gloria funda; / tú que por Dios valerosa / luchaste siete centurias / y la cruz de Dios pusiste / sobre la infiel media-luna» - subraya en Libertades y lluvias -.$^{96}$ En este desarrollo a lo largo del tiempo se detiene en el reinado de los reyes católicos por la unidad política y religiosa lograda, resaltando a Isabel para asumir el sesgo castellanista en la construcción nacional e imperial («la reina de Castilla, / reina de dos mundos es!») e identificar su figura con la de Isabel II. ${ }^{97}$ En esta reina, para Antonio Trueba, como para el grueso de los conservadores, concluye la historia, es la síntesis de los tiempos, cuando la Monarquía, siguiendo la tradición, se convierte en católica y nacional. ${ }^{98}$ Además, él manifiesta una ferviente fidelidad a Isabel II, retratándola en El estilo de hombre como una monarca muy magnánima y compasiva ${ }^{99}$ y en El tío Miserias

\footnotetext{
92 Trueba 1862c, 210-211.

93 Trueba 1862 a, $179-202$ y 410.

94 Cirujano, Elorriaga y Pérez 1985, 91-98 y Jover 1991, 165-169.

95 Trueba $1866 \mathrm{~b}, 90$.

96 Trueba, 1867, 63.

97 Isabel la Católica en Trueba, 1862a, 373-376.

98 Cánovas 1982, 303-308.

99 Trueba 1862c, 345-349. En esta misma línea en el poema
} Introducción de Trueba 1862a, 21 le rinde un auténtico homenaje: «iNoble reina de Castilla! / yo te tributo homenaje / porque a su Dios como una reina muy hospitalaria y caritativa, haciéndole ir a «visitar, consolar y socorrer a una pobre anciana que agonizaba en una buhardilla de Lavapiés». ${ }^{100}$ Por eso no puede por menos en la narración Lozoya, que cuenta la canalización de este río, hacer que a su llegada a Madrid rinda pleitesía a Isabel II y transforme los campos de alrededor del palacio real en un magnifico jardín. ${ }^{101}$

También, en línea con el ala más conservadora de los moderados, defiende la necesidad de afirmar la autoridad monárquica. Así, en El yerno del rey, interpreta desde esa perspectiva el principio de la soberanía compartida, al hacerle decir al monarca del cuento que «eso que el rey reina y no gobierna no va conmigo", y también critica las limitaciones establecidas por la Constitución al rey. ${ }^{102} \mathrm{El}$ modelo que propugna, como hace en Las aventuras un sastre, es el de un monarca ilustrado, pero gobernando en favor del pueblo porque "hoy para ceñir una corona - afirma el sastre que logra acceder al trono- no basta tener derecho a ella, se necesita hacerse digno de ceñirla a fuerza de ingenio y trabajo». ${ }^{103}$

Pero, para poder dirigir sabiamente la nave de Estado, la reina necesita consejeros y funcionarios leales y comprometidos con la causa pública. Así lo señala Antonio Trueba en el cuento La compota, en el que, junto a El yerno de rey y El preste Juan de Indias, principalmente, realiza una dura crítica al sistema político imperante en España, a su clase política, a los partidos, a las instituciones parlamentarias y a la administración y a la función pública por estar dominados por los intereses particulares y egoístas personales, así como por las corruptelas y favoritismos. Tampoco escapan de la censura los pronunciamientos, la intervención de los militares en la política y del pueblo, que, para Antonio Trueba, cuando se insurrecciona, no es tal, sino populacho. ${ }^{104}$ Solo se salva, junto a «la buena, la compasiva, la magna Isabel», la guardia civil, a la que acentuando su carácter abnegado y servicial («el poder que al bueno sirve de perenne salvaguardia», "sublimes héroes de la caridad cristiana», "ángel custodio», "nuncio de la esperanza»), homenajea con un largo poema en el Libro de los cantares, que tiene como estribillo: «Viva la Guardia civil porque es la gloria de España». ${ }^{105}$

También otorga el calificativo de populacheras a las doctrinas igualitaristas y socialistas. De ellas se mofa el escritor vizcaíno en distintas páginas de las narraciones con el objeto de afirmar el carácter natural y necesario de la desigualdad. Lo hace en La resurrección del alma mediante

y a su Rey / reverenciaron mis padres, / porque además de ser Reina, / el corazón tienes grande, / porque además de ser buena, / eres mujer y eres madre...".

100 Trueba 1866b, 285. Aunque realiza una revisión historiográfica sobre el reinado isabelino, en Trueba 1874, 198-200 mantiene su visión sobre la reina. Narra el viaje que realizó a las provincias Vascongadas en 1865 , señalando que dejó en ellos «grata memoria de su piedad y caridad inagotable», así como de "esperanza y consuelos verdaderamente maternales».

101 Trueba 1862c, 301-302.

102 Trueba $1866 \mathrm{~b}, 134$.

103 Trueba 1866a, 204.

104 Trueba $1875,299-301 ; 1866 b, 135-136$ y 1866a, 5-10.

105 Trueba 1862a, 380-391. Este homenaje está directamente relacionado con la colaboración de Antonio Trueba desde 1849 en el periódico oficial de la benemérita. 
un diálogo entre un gato llamado Marroño, que es comunista y considera que la "propiedad es un robo", y un perro conocido como Navarro, que no lo es, pero recurre al principio esgrimido por aquél para arrebatarle la comida. ${ }^{106} \mathrm{En}$ Crispín y Crispiniano, Antonio Trueba retrata a dos zapateros borrachos que, como siempre están discutiendo sobre el pauperismo y el proletariado, se convierten «el primero presidente y el segundo secretario de una sociedad niveladora, que tiene por título El Rasero, y donde los dos cogen cada chispa que llaman a Cristo de tú ». ${ }^{107}$

Igualmente, por ser contrarias a lo que Dios manda, denigra la literatura francesa, la política y social, que dio cobertura a la para él nada aleccionadora Revolución francesa (Rafael, el ateo del cuento Creo en Dios, consideraba a Voltaire su evangelio), y la folletinesca popular, por su carácter escasamente moralizante, pero, sobre todo, porque estaba siendo imitada en España. ${ }^{108}$ Como ya hemos visto, presentaba a Fernán Caballero y a él mismo como alternativa porque la literatura española no tenía nada que envidiar a la ajena. De la misma manera, para nuestro narrador, pasa con la nación española, si nos atenemos al gran desengaño que sufrió Pedro, protagonista principal de Desde la patria al cielo, a largo de su recorrido por tierras extranjeras europeas y americanas. Eso sí, para afirmar el orgullo nacional, los lectores reciben una imagen distorsionada y esperpéntica de esos lugares, ${ }^{109}$ que no es más que un alegato contra el progreso y la modernidad.

\section{CONCLUSIONES}

Desde el principio la formación cultural de la nación española estuvo acompañada de la religión católica, sobre todo, en la formulación conservadora. Pero, después de la deriva social de la nación en las revoluciones de 1848 y en el bienio progresista en España, el sector más retrógrado de esa tendencia la hizo ocupar un lugar central en su concepción nacional, esbozando la que se puede considerar primera versión del nacional catolicismo. Para esta exclusiva identificación de la nación española y de los españoles con el catolicismo, se procedió a su construcción cultural mediante, principalmente, la definición de unos soportes ideológicos doctrinales con una impronta muy eclesial, la propuesta de articulación de un sistema político monárquico muy apegado a la constitución histórica, la relectura de la historia conforme al mito historiográfico nacional católico y la elaboración de un relato nacional que permitiera aprehender la comunidad imaginada bajo ese paradigma confesional y un modelo social conservador a ultranza.

A este respecto, dado su papel fundamental en los procesos de nacionalización, se recurrió, entre otros medios, a la prensa y a la literatura de ficción. En esta aportación narrativa de los conservadores, definida por su carácter instructivo y moralizador, destacó la escuela formada en torno a la obra de Fernán Caballero y descolló uno de sus alumnos más aventajados, el vizcaíno Antonio Trueba. El éxito que éste logró con sus cuentos y poemas en los años

\footnotetext{
106 Trueba $1862 b, 45$ y 82.

107 Trueba 1866b, 232.

108 Trueba 1862 b, 378 y 1862 c, 351.

109 Trueba 1862b, 170-199.
}

centrales de la Monarquía isabelina se debió a la sensibilidad e ingenuidad transmitida, al lenguaje sencillo y llano y a su cercanía y familiaridad. Así, consiguió captar a un número importante de lectores a través de un lenguaje creado por él que hace pasar por popular, mediante unos relatos inspirados y desarrollados, principalmente, en la tierra natal de Las Encartaciones y, ocasionalmente, en la tierra de acogida de Madrid, y escenificados en un entorno aldeano y un paisaje rural sumamente idealizado, y por medio de unas tramas en las que, privilegiando los aspectos costumbristas, folklóricos y tradicionales populares, cuentan con unos argumentos y personajes planos, simples y pueriles. En fin, un nutrido público se vio atraído y aleccionado por una literatura como la de Antonio Trueba, siempre orientada por una moral católica muy ortodoxa y una ideológica muy conservadora, que, en su caso, era la expresión más genuina de la doble identidad compartida o doble patriotismo, español y vasco, característico del fuerismo de la época isabelina, al que pertenecía.

En el primer patriotismo, al que hemos dedicado este estudio, se recoge la contribución del escritor vizcaíno al arranque del futuro nacional catolicismo. Fundamentalmente, la realiza siguiendo los parámetros fundamentales que guían toda su obra, Dios, la familia y la patria. El primero de ellos lo contempla a partir de la afirmación de la religión católica como "única verdadera» frente a otras confesiones cristianas y no cristianas y, sobre todo, frente al "racionalismo ateo», que es el que más denigra. Desde esta perspectiva, para Antonio Trueba, la religión católica exige una fe militante, que se pone a prueba con la resignación ante los designios inescrutables de Dios y se compensa con la esperanza en el reino de los cielos, siempre y cuando se lleve una vida caritativa. Pues bien, detrás de la catequización, que en su narrativa realiza sobre el cumplimiento de estas virtudes teologales, se encuentra la aceptación del orden social existente.

La familia para Antonio Trueba es la institución nuclear creada por Dios. Sigue el modelo tradicional patriarcal, asentado en la "superioridad moral y física» del hombre, al que le incumbe el mantenimiento de sus miembros por medio del trabajo, la defensa del honor y el apellido familiar y la perpetuación de la casa solar, y en la supeditación de la mujer, a la que le corresponde el buen gobierno del hogar, el cuidado y educación de los hijos y el amor, respeto y ayuda al marido. En ambos casos, como la familia, el hombre y la mujer deben ser inexcusablemente buenos católicos. Pues bien, así organizada, esta célula social alcanza la verdadera felicidad trabajando y compartiendo la vida con los convecinos de la aldea. Ésta, para el escritor encartado, es una comunidad que, teniendo su centro de gravedad en la parroquia, complementa a la familia en la adversidad y en la alegría. Pues bien, es aquí en donde encuentra «el más fecundo manantial de patriotismo», la verdadera esencia nacional, ya que esta "patria chica», desde la perspectiva conservadora católica, encarna la religiosidad, la salvaguarda de las costumbres y tradiciones, el amor a la familia y al trabajo, el respeto al orden, a la propiedad y a las jerarquías reconocidas, la naturalidad, austeridad, sencillez y conformismo.

Sobre esta "patria chica» Antonio Trueba levanta la «patria grande». Esta, la nación y la historia nacional, la concibe a la manera moderada, claramente retrospectiva 
y tradicional, identificando la monarquía con el Estado y la consecución de la unidad religiosa y política, con el único fin de afirmar a la Monarquía isabelina como católica y nacional. Por eso, a la falta de una aportación novedosa, lo importante es la divulgación que lleva a cabo a través de sus cuentos y poemas de los grandes mitos de la reconquista, de los reyes católicos, de la guerra de la independencia y del propio reinado de Isabel II desde una perspectiva historiográfica nacional católica.

\section{FUENTES}

Trueba, Antonio. 1862a. El libro de los cantares. 5a ed. Madrid: Imprenta de D. Luis Palacios.

Trueba, Antonio. 1862b. Cuentos de color de rosa. 2a ed. Hecha de orden y a expensas de S.M. la Reina. Madrid: Imprenta de D. Luis Palacio.

Trueba, Antonio. 1862c. Cuentos campesinos. 2ª ed. Hecha de orden y a expensas de S.M. la Reina. Madrid: Imprenta de D. Luis Palacios.

Trueba, Antonio. 1864. Capítulos sentidos y pensados viajando por las provincias Vascongadas. Madrid: Centro General de la Administración.

Trueba, Antonio. 1866a. Cuentos de varios colores. Madrid: Imprenta del Centro General de la Administración.

Trueba, Antonio. 1866b. Cuentos de vivos y muertos, contados por el pueblo. Madrid: Librería Leocadio López, editor.

Trueba, Antonio. 1867. El libro de las montañas. Bilbao: Librería de D. Agustín Emperaile, editor.

Trueba, Antonio. 1870. Bosquejo de la organización social de Vizcaya. Publicase en virtud de acuerdo de este M.N. y M.L. Señorío, congregado en Junta General so el árbol de Guernica. Bilbao: Juan E. Delmas, impresor del Señorío.

Trueba, Antonio. 1874. Mari-Santa, cuadros de un hogar y sus contornos. Madrid: A. de Carlos e Hijo, editores.

Trueba, Antonio. 1875. Cuentos populares. Leipzig: F. A. Brockhaus.

Trueba, Antonio. 1878. Madrid por fuera. Madrid: Agustín Jubera.

Trueba, Antonio. 1889. «Notas autobiográficas». La llustración española y americana $\mathrm{n}$ - IV: 59-63.

Trueba, Antonio. 1905. Cuentos del hogar. Madrid: Librería de Antonino Romero.

\section{BIBLIOGRAFÍA COMPLEMENTARIA}

Abellán, José Luis. 1984. Historia crítica del pensamiento español. 5. Liberalismo y romanticismo (1808-1874). Barcelona: Círculo de Lectores.

Alonso, Gregorio. 2014. La nación en capilla. Ciudadanía católica y cuestión religiosa en España (1793-1874). Granada: Comares.

Álvarez Junco, José. 2001. Mater Dolorosa. La idea de España en el siglo XIX. Madrid: Taurus.

Amores García, Montserrat. 1999. Antonio de Trueba y el cuento popular. Bilbao: Departamento de Cultura de la Diputación Foral de Bizkaia.

Amores García, Montserrat. 2001. Fernán Caballero y el cuento folclórico. El Puerto de Santa María: Ayuntamiento El Puerto de Santa María.

Anderson, Benedict. 1993. Comunidades imaginadas. Reflexiones sobre el origen y la difusión del nacionalismo. México: Fondo de Cultura Económica.

Andreu Miralles, Xavier. 2012. «La mujer católica y la regeneración de España: genero, nación y modernidad en Fernán Caballero». Mélanges de la Casa Velázquez 42 (2): 17-35. https://doi.org/10.4000/mcv.4514

Andreu Miralles, Xavier. 2016. El descubrimiento de España. Mito romántico e identidad nacional. Barcelona: Taurus.

Andreu Miralles, Xavier. 2017. «Articular la nación. La María de Ayguals de Izco y la nacionalización española (1845-1850)». Rúbrica
Contemporánea 6 (11): 25-43. https://doi.org/10.5565/rev/ rubrica.135

Ballbé, Manuel. 1983. Orden público y militarismo en la España constitucional (1812-1983). Madrid: Alianza Editorial.

Baquero Goyanes, Mariano. 1992. El cuento español del romanticismo al realismo. Madrid: CSIC.

Bhabha, Homi K. 2010. Nación y narración. Entre la ilusión de la identidad y las diferencias culturales. Buenos Aires: Siglo XXI.

Becerro Bengoa, Ricardo. 1892. Trueba. Estudio biográfico. Madrid: La España Moderna.

Becerro Bengoa, Ricardo. 1896. En honor de Trueba. Bilbao: Imprenta de la Biblioteca Bascongada.

Botti, Alfonso. 1992. Cielo y dinero. El nacional-catolicismo en España (1881-1875). Madrid: Alianza Editorial.

Burdiel, Isabel. 2010. Isabel II. Una biografía (1830-1904). Madrid: Taurus.

Burdiel, Isabel. 2015. "Lo que las novelas pueden decir a los historiadores. Notas para Manuel Pérez Ledesma». En El historiador consciente. Homenaje a Manuel Pérez Ledesma, coord. José Álvarez Junco, Rafael Cruz y Florencia Peyrou, 263-281. Madrid: Marcial Pons - UAM Ediciones.

Callahan, William J. 1989. Iglesia, poder y sociedad en España, 17501874. Madrid: Nerea.

Castro Alfín, Demetrio. 1998. Los males de la imprenta. Política y libertad de prensa en una sociedad dual. Madrid: Centro de Investigaciones Sociológicas.

Cánovas Sánchez, Francisco. 1982. El partido moderado. Madrid: Centro de Estudios Constitucionales.

Cirujano Marín, Paloma, Teresa Elorriaga Planes y Sisinio Pérez Garzón. 1985. Historiografía y nacionalismo español. Madrid: CSIC - Centro de Estudios Históricos.

Ereño Altuna, José Antonio. 1998. Antonio de Trueba: literatura-historia-política (con la disculpa de unos artículos de Trueba). Bilbao: J. A. Ereño.

Fuentes, Juan Francisco. 2013. «Conceptos previos: Patria y nación en los orígenes de la España contemporánea» En Historia de la nación y del nacionalismo español, coord. Antonio Morales Moya, Juan Pablo Fusi Aizpurúa y Andrés de Blas Guerrero, 169-196. Madrid: Fundación Ortega-Marañón - Galaxia Gutenberg-Círculo de Lectores.

Garrido Muro, Luis. 2013a. «Dos naciones en una. La nación progresista». En Historia de la nación y del nacionalismo español, coord. Antonio Morales Moya, Juan Pablo Fusi Aizpurúa y Andrés de Blas Guerrero, 263-276. Madrid: Fundación Ortega-Marañón - Galaxia Gutenberg-Círculo de Lectores.

Garrido Muro, Luis. 2013b. «Esta estúpida nación. La nación moderada». En Historia de la nación y del nacionalismo español, coord. Antonio Morales Moya, Juan Pablo Fusi Aizpurúa y Andrés de Blas Guerrero, 277-292. Madrid: Fundación Ortega-Marañón - Galaxia Gutenberg-Círculo de Lectores.

Gómez Prieto, Julia. 1989. "Sus caminos y paisajes encartados». En Centenario de Antonio Trueba, José Antonio Arana Martija, 11-16. Bilbao: Caja de Ahorros Vizcaína.

González-Blanco, Andrés. 1914. Antonio de Trueba: su vida y sus obras (páginas escogidas). Bilbao: Librería de Villar.

Haupt, Heinz-Gerhard. 2006. «Religión y nación en la Europa del siglo XIX: algunas consideraciones en perspectiva comparada». Alcores 2: 159-175.

Haupt, Heinz-Gerhard y Dieteer Langewiesche. 2010. «Introducción». En Nación y religión en Europa. Sociedades multiconfesionales en los siglos XIX y XX, ed. Heinz-Gerhard Haupt y Dieteer Langeswiesche, 23-36. Zaragoza: Institución «Fernando el Católico» (CSIC) - Excma. Diputación de Zaragoza.

Hayes, Carlton. 1966. El nacionalismo, una religión. México: UTEHA. Iglesia, Ángel. 1975. Antonio de Trueba. Bilbao: Caja de Ahorros Vizcaína. Inarejos Muñoz, Juan Antonio. 2008. «Sotanas, escaños y sufragios. Práctica política y soportes sociales del neocatolicismo en las provincias castellano-manchegas (1854-1868)». Hispania Sacra LX, 121: 297-329. https://doi.org/10.3989/hs.2008.v60.i121.57 
Jover Zamora, José María. 1991. La civilización española a mediados del s. XIX. Madrid: Espasa Calpe.

Juaristi, Jon. 1987. El linaje de Aitor. La invención de la tradición vasca. Madrid: Taurus.

Juaristi, Jon. 1989. «Trueba, narrador». En Centenario de Antonio Trueba, José Antonio Arana Martija, 57-64. Bilbao: Caja de Ahorros Vizcaína.

López Aranguren, José Luis. 1982. Moral y sociedad. Introducción a la moral social española del siglo XIX. Madrid: Taurus.

Louis-Lande, Lucien. 1905. «Un narrador español. Antonio de Trueba», traducción y anotación por Antonio Trueba de «Un Conteur espag nol contemporain - Antonio de Trueba» Revue des Deux Monde, 3er période, tome 13: 410-432 en A. Trueba, Cuentos del hogar: 317-369. Madrid: Librería Antonio Romero.

Louzao Villar, Joseba. 2013. «Nación y catolicismo en la España contemporánea. Revisitando una interrelación histórica». Ayer 90: 65-89.

Marcuello Benedicto, Juan Ignacio. 2016. Los proyectos de reforma politica de Bravo Murillo en perspectiva. Conservadurismo autoritario y antiparlamentarismo en la Monarquía de Isabel II. Oviedo: In Itinere.

Millán, Jesús y María Cruz Romeo. 2010. «Presentación. La religión en la trayectoria de los Estados nacionales: retos y diálogos en perspectiva histórica». En Nación y religión en Europa. Sociedades multiconfesionales en los siglos XIX y XX, ed. Heinz-Gerhard Haupt $y$ Dieteer Langeswiesche, 9-19. Zaragoza: Institución «Fernando el Católico» (CSIC) - Excma. Diputación de Zaragoza.

Millán, Jesús y María Cruz Romeo. 2015. «La cuestión católica en el liberalismo. Las perspectivas sobre la unidad religiosa en la España liberal, 1808-1868». Historia y Política 34: 183-209.

Mina Apat, María Cruz. 1990. "Historia y política: las vicisitudes de una ley». En 150 años del Convenio de Bergara y la ley de 25-X1839, ed. Joseba Agirreazkuenaga y José Ramón Urquijo, 269-317. Vitoria-Gasteiz: Parlamento Vasco.

Mínguez Blasco, Raúl. 2016. Evas, Marías y Magdalenas. Género y modernidad católica en la España liberal (1833-1874). Madrid: Asociación de Historia Contemporánea - Centro de Estudios Políticos y Constitucionales.

Mínguez Blasco, Raúl. 2017. «La novela y el surgimiento del neocatolicismo en España. Una Interpretación de género». Espacio, Tiempo y Forma. Serie V, Historia Contemporánea 29: 129-148. http://doi.org/10.5944/etfv.29.2017.19012

Mínguez Blasco, Raúl. 2018. «Liberalismo y catolicismo ante el espejo. La construcción de las feminidades decimonónicas». En Mujeres, hombres y catolicismo en la España contemporánea. Nuevas visiones desde la historia, ed. Inmaculada Blasco Herranz, 25-45. Valencia: Tirant Humanidades.

Molina Aparicio, Fernando. 2005. La tierra del martirio español. El País Vasco y España en el siglo del nacionalismo. Madrid: Centro de Estudios Políticos y Constitucionales.

Montesinos, José F. 1970. "Trueba y su realismo». En Ensayos y estudios de literatura española, 227-246. Madrid: Revista de Occidente.

Mosse, George L. 2005. La nacionalización de las masas. Simbolismo político y movimientos de masas en Alemania desde las guerras napoleónicas al tercer Reich. Madrid: Marcial Pons.

Múgica, Gregorio. 1914. Trueba: su significación en la moderna literatura vasca. San Sebastián: Imprenta Martín, Mena y C.
Paliza Mondaute, María Teresa. 2004. «El monumento al poeta Antonio Trueba, obra de Mariano Benlliure y su influencia en la escultura conmemorativa vizcaína del siglo XX». Ondare. Cuadernos de artes plásticas y monumentales 23: 437-453.

Peers, Edgar Allison. 1967. Historia del movimiento romántico español. Vol. II. Madrid: Gredos.

Pérez Núñez, Javier. 2002. «La Diputación foral o la síntesis al contencioso decimonónico entre Fueros y Constitución». En Los liberales. Fuerismo y liberalismo en el País Vasco (1808-1876), coord. Coro Rubio Pobes y Santiago de Pablo, 199-226. Vitoria-Gazteiz: Fundación Sancho El Sabio.

Pérez Núñez, Javier. 2016. «Conmemorar la nación desde abajo. Las celebraciones patrióticas del Madrid progresista, 1836-1840». Historia y Política 35: 177-202. https://doi.org/10.18042/hp.35.08.

Pérez Núñez, Javier. 2020. «La comunidad imaginada por Antonio Trueba: ¿el paraíso foral vasco durante la Monarquía isabelina?». En Escribir identidades. Diálogos entre la Historia y la Literatura, ed. Carmen de la Guardia Herrero, Florencia Peyrou Tubert y Pilar Toboso Sánchez, 47-73. Madrid: Síntesis.

Portillo Valdés, José María. 2000. Revolución de nación. Orígenes de la cultura constitucional en España, 1780-1812. Madrid: Centro de Estudios Políticos y Constitucionales - Boletín Oficial del Estado.

Portillo Valdés, José María. 2006. El sueño criollo. La formación del doble constitucionalismo en el País Vasco y Navarra. Donostia-San Sebastián: Nerea.

Quiroga, Alejandro. 2013. «La nacionalización de España. Una propuesta teórica». Ayer 90: 17-38.

Romeo Mateo, María Cruz. 2010. «¿Qué es ser neocatólico? La crítica antiliberal de Aparisi y Guijarro». En «Por Dios, por la Patria y el Rey». Las ideas del carlismo. IV Jornadas de Estudio del Carlismo, 129-163. Pamplona: Gobierno de Navarra.

Romeo Mateo, María Cruz. 2017. «¿Sujeto católico femenino? Política y religión en España». Ayer 106: 79-104.

Romeo Mateo, María Cruz. 2018. «El otro género de la religión: la masculinidad católica en la España isabelina». En Mujeres, hombres y catolicismo en la España contemporánea. Nuevas visiones desde la historia, ed. Inmaculada Blasco Herranz, 69-91. Valencia: Tirant Humanidades.

Rubio Pobes, Coro. 2003. La identidad vasca. Discurso y agentes sociales. Madrid: Biblioteca Nueva.

Suárez Cortina, Manuel. 2014. Entre cirios y garrotes. Política y religión en la España contemporánea, 1808-1936. Santander: Ediciones Universidad de Cantabria.

Urigüen González, Begoña. 1981. Origen y evolución de la derecha española: el neocatolicismo. Madrid: CSIC.

Urquijo, Mikel. 2000. Dos aproximaciones a la sociedad vasca del ochocientos. Bilbao: Servicio Editorial de la Universidad del País Vasco.

Villalonga, Borja. 2012. «La nación católica: Balmes y la representación de España en el ochocientos». Historia Social 72: 49-64.

Zavala, Iris M. 1989. "La literatura: romanticismo y costumbrismo». En Historia de España Menéndez Pidal. La época del romanticismo (1808-1874). Las letras, las artes, la vida cotidiana, coord. Hans Juretschke, t. 35, v. 2, 4-183. Madrid: Espasa Calpe. 